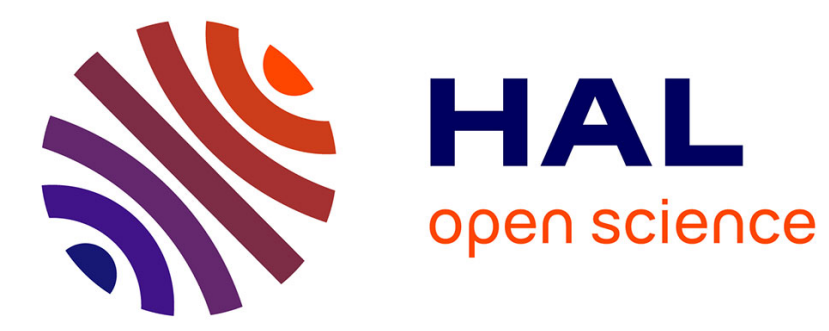

\title{
Variability in the structure of epiphytic assemblages of in relation to human interferences in the Gulf of Gabes, Tunisia
}

\author{
Mounir Ben Brahim, Asma Hamza, Imen Hannachi, Ahmed-Riadh Rebai, \\ Othman Jarboui, Abderrahmen Bouain, Lotfi Aleya
}

\section{To cite this version:}

Mounir Ben Brahim, Asma Hamza, Imen Hannachi, Ahmed-Riadh Rebai, Othman Jarboui, et al.. Variability in the structure of epiphytic assemblages of in relation to human interferences in the Gulf of Gabes, Tunisia. Marine Environmental Research, 2010, 70 (5), pp.411. 10.1016/j.marenvres.2010.08.005 . hal-00631670

\section{HAL Id: hal-00631670 \\ https://hal.science/hal-00631670}

Submitted on 13 Oct 2011

HAL is a multi-disciplinary open access archive for the deposit and dissemination of scientific research documents, whether they are published or not. The documents may come from teaching and research institutions in France or abroad, or from public or private research centers.
L'archive ouverte pluridisciplinaire HAL, est destinée au dépôt et à la diffusion de documents scientifiques de niveau recherche, publiés ou non, émanant des établissements d'enseignement et de recherche français ou étrangers, des laboratoires publics ou privés. 


\section{Accepted Manuscript}

Title: Variability in the structure of epiphytic assemblages of Posidonia oceanica in relation to human interferences in the Gulf of Gabes, Tunisia

Authors: Mounir Ben Brahim, Asma Hamza, Imen Hannachi, Ahmed Rebai, Othman Jarboui, Abderrahmen Bouain, Lotfi Aleya

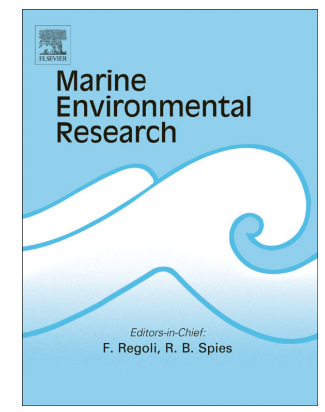

PII:

S0141-1136(10)00120-0

DOI:

10.1016/j.marenvres.2010.08.005

Reference: MERE 3471

To appear in: Marine Environmental Research

Received Date: 25 March 2010

Revised Date: 31 July 2010

Accepted Date: 16 August 2010

Please cite this article as: Ben Brahim, M., Hamza, A., Hannachi, I., Rebai, A., Jarboui, O., Bouain, A., Aleya, L. Variability in the structure of epiphytic assemblages of Posidonia oceanica in relation to human interferences in the Gulf of Gabes, Tunisia, Marine Environmental Research (2010), doi: 10.1016/ j.marenvres.2010.08.005

This is a PDF file of an unedited manuscript that has been accepted for publication. As a service to our customers we are providing this early version of the manuscript. The manuscript will undergo copyediting, typesetting, and review of the resulting proof before it is published in its final form. Please note that during the production process errors may be discovered which could affect the content, and all legal disclaimers that apply to the journal pertain. 
1 Variability in the structure of epiphytic assemblages of Posidonia oceanica in relation to

6 Mounir Ben Brahim ${ }^{1,2}$, Asma Hamza ${ }^{2}$, Imen Hannachi ${ }^{1,2}$, Ahmed Rebai $^{3}$, Othman Jarboui ${ }^{2}$, $7 \quad$ Abderrahmen Bouain ${ }^{1}$ and Lotfi Aleya* ${ }^{4}$

$10{ }^{1}$ Université de Sfax, Faculté des Sciences Sfax. Route Soukra Km 3.5, BP: 802, 3018 Sfax.

11 Tunisia

$12{ }^{2}$ Institut National des Sciences et Technologies de la Mer, Centre de Sfax, Rue Madagascar, 13 BP 1035, Sfax, CP 3018, Tunisie.

$14{ }^{3}$ Centre de Biotechnologie de Sfax, Route Sidi Mansour Km 6, Sfax, Tunisie

${ }^{4}$ Université de Franche-Comté, Laboratoire de Chrono-Environnement, UMR CNRS 62491 , 16 Place Leclerc, F-25030 Besançon cedex, France.

17

18 
1 Abstract

2 In this study we evaluate whether the pattern of spatial variability of the macro-epiphytes

3 assemblages of leaves of Posidonia oceanica differed in relation to anthropogenic

4 interference in the Gulf of Gabes (southern coast of Tunisia). A hierarchical sampling design

5 was used to compare epiphytic assemblages at $5 \mathrm{~m}$ depth in terms of abundance and spatial

6 variability at disturbed and control locations. The results indicate that the biomass and mean

7 percentage cover decreased at locations near the point of sewage outlet in comparison to

8 control locations. These losses were related to the distance from the source of disturbance.

9 This study revealed that the diversity is reduced in disturbed locations by the loss of biomass

10 and the mean percentage cover, explained by means of a multiple-stressor model which plays

11 an important role in the macro-epiphytes setting. It is urgent to propose the best management

12 plans to save the remaining $P$. oceanica meadow in the Gulf of Gabes and its associated

13 epiphytes.

14

15

16 Keywords: Macro-epiphytes ; Posidonia oceanica; disturbance ; spatial variability ; Gabès 17 Gulf. 


\section{Introduction}

2 Over the past 20 years, the Gulf of Gabes, on the southeast coast of Tunisia, has produced

3 more than $65 \%$ of the annual fish yield in Tunisia (Ben Mustapha, 1995; C.G.P., 1996), being

4 favoured by widespread seagrass beds widely recognized as key ecosystems in temperate and

5 tropical infra littoral habitats (Hemminga and Duarte, 2000; Boudouresque et al., 2009).

6 However, fish production is gradually decreasing parallel to the decline of littoral beds of the

7 endemic Mediterranean seagrass Posidonia oceanica (L.) Delile species as the coastal area of

8 the Gulf is now a threatened biotope mainly due to the pressure of anthropogenic expansion

9 and dumping of large quantities of phosphogypsum and other chemical products which severely impacted benthic habitats ((Hamza-Chaffai et al., 1999, Bejaoui et al., 2004). The

11 loss of the native vegetable cover in the Gulf of Gabes is estimated at $90 \%$ with the $P$. oceanica beds being replaced by the opportunistic and caulerpenyne-producing green algae Caulerpa prolifera (Forsskål) Lamouroux in deeper zones (Hamza et al., 1995; Ramos-Espla et al., 2000). The remaining Posidonia meadows cover the littoral fringes at depths ranging between -3 and $-4 \mathrm{~m}$ (Hattour et al., 1998). On the other hand, most biological studies of the Gulf of Gabes have dealt with the distribution of phytoplankton (Drira et al., 2008; Bel Hassen et al., 2009) zooplankton (Drira et al., 2009) ciliates (Kchaou et al., 2009; Hannachi et al., 2009), demosponges (Ben Mustapha et al., 2003) while seagrass species and their epiphytes which are known to be highly sensitive to environmental changes (Balata et al., 2007; Prado et al., 2008; Montefalcone, 2009) have been given limited attention. Epiphytes of seagrass not only contribute significantly to the primary production of the meadow (Buia et al., 1992; Nelson and Waaland, 1997; Duarte et al., 2004), but are also more sensitive to environmental changes than the plant host (Delgado et al., 1999; Nesti et al., 2008; 
1 (Balata et al., 2008; Frankovich et al., 2009) and water quality (Meric et al., 2005).

2 Differences in the spatial heterogeneity of epiphytes (Piazzi et al., 2004; Martínez-Crego et

3 al., 2010) and shifts in species composition (Nesti et al., 2008; Fourqurean et al., 2010) have

4 also been observed. It is widely known that the distribution of epiphytic assemblages of $P$.

5 oceanica both on leaves (Van der Ben., 1971; Mazzella et al., 1989) and rhizomes (Piazzi et

6 al., 2002; Balata et al., 2008) can change, but these changes have not yet been explored on a

7 horizontal scale in the Gulf of Gabes. Differences in the spatial heterogeneity of epiphytes

8 (Piazzi et al., 2004) and shifts in species composition (Nesti et al., 2008; Fourqurean et al.,

2010; Martínez-Crego et al., 2010) have also been observed. Several findings have provided evidence that epiphytes are patchy at 1 to $10 \mathrm{~cm}$ (Kendrick and Burt, 1997; Jernakoff and Neilsen, 1998) and > kilometer scales, (Vanderklift and Lavery 2000, Lavery and Vanderklift 2002), other studies have indicated that epiphytes may be uniform at relatively small spatial scales (e.g., 0.1 m Vanderklift and Lavery 2000; <10 m, Saunders et al., 2003, Piazzi et al., 2004). Moore et al. (2006) reported that epiphytes biomass is uniform at the scale $<100 \mathrm{~m}$ transect. Variability in leaves epiphytic biomass at the scale of meters may be relatable to differences in shoot density (Gambi et al., 1989), and to impacts of water movements on both settlement and recruitment of propagules (Trautman and Borowitzka, 1999; Vanderklift and Lavery, 2000). It is, therefore, of importance to undertake a study of the effects of urban pressure on $P$. oceanica dynamics under the impact of human activities versus control conditions. To our knowledge, only the flowering and fructification of P. oceanica along the coastline of the Gulf of Gabes has been the subject of studies in recent years (Hattour et al., 1998). As part of a comprehensive study intended to understand the dramatic decline of the endemic Mediterranean seagrass $P$. oceanica in the Gulf of Gabes, we analyzed, for the first time in this ecosystem, the structure and patterns of spatial variability of leaf macro-epiphytic assemblages and tested their relationships with anthropogenic disturbance. We attempted to 
1 answer the questions 1) how vulnerable are the leaf macro-epiphytic assemblages to these

2 environmental pressures? 2) Does epiphyte biomass increase parallel with organic and

3 nutrient enrichment and which members of the epiphytic community should be considered as

4 most sensitive species? And 3) Does anthropogenic disturbance modify the spatial scales at

5 which variability of the epiphytic communities is highest/lowest or also influences the

6 partition of total variability among spatial scales? We, thus, compared epiphytic assemblages

7 between locations exposed to urban and industrial effluents and control locations, and 8 examined their variability at spatial scales ranging from $\mathrm{cm}$ to $\mathrm{km}$, using a hierarchical

9 sampling design (Underwood, 1994; Chapman et al., 1995).

\section{Material and methods}

\subsection{Study area}

The Gulf of Gabes is located between $35^{\circ} \mathrm{N}$ and $33^{\circ} \mathrm{N}$ and extends from "Ras kapoudia" at the $35^{\circ} \mathrm{N}$ parallel level to the Tunisian-Libyan border (Fig. 1). It shelters various islands (Kerkennah and Djerba) and lagoons (Bougrara and El Bibane). The climate is dry (average precipitation: $210 \mathrm{~mm} \mathrm{year}^{-1}$ ) and sunny with strong easterly winds. The tide is semidiurnal, with a maximum range of about $2 \mathrm{~m}$.

Because the $P$. oceanica epiphytic community reaches its optimum seasonal development in summer (Romero, 1988) fieldwork was conducted in July-August 2006. Four locations distant

$2130 \mathrm{~km}$ from each other were chosen for the samplings. The depth of all stations was $5 \mathrm{~m}$ and temperature and salinity ranges were $27^{\circ} \mathrm{C}-30^{\circ} \mathrm{C}$ and $38-40$ P.S.U., respectively. Two locations were disturbed by a sewage discharge: Ghannouch ( $\left.34^{\circ} 30^{\prime} 523^{\prime \prime} \mathrm{N} 10^{\circ} 54^{\prime} 743^{\prime \prime} \mathrm{E}\right)$ and Zarrat (33 43'417" N 10 $20^{\circ} 486^{\prime \prime}$ E) labeled herein respectively, D1 and D2. The other 


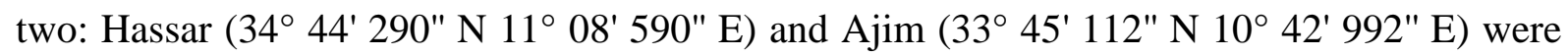

2 control locations, located north and south of the disturbed area and labeled respectively, C1

3 and C2. Within each location (D1, D2, C1, C2), three sites were randomly selected, 500-600

$4 \mathrm{~m}$ apart, and within each site two sub-sites were also randomly selected. Each sub-site was

5 randomly divided into three plots, each plot then being divided into three quadrats $20 \mathrm{~cm}$

6 apart. We examined variability at tens of centimeter-scale by collecting samples from the

7 same quadrat. This quadrat was $20 \mathrm{~cm} \times 20 \mathrm{~cm}$ and divided into a grid of $10 \mathrm{~cm} \times 10 \mathrm{~cm}$ sub-

8 quadrats.

\subsection{Data collection}

The density of $P$. oceanica shoots was estimated from 216 replicates present within $100 \mathrm{~cm}^{2}$

11 sub-quadrats inside each meadow. Five shoots were randomly collected from each subquadrat during SCUBA diving and preserved in seawater-formalin (5\%) solution for species identification in the laboratory. Leaf length corresponds in fact to the average evaluated from each meadow. The samples were examined for leaf surface per shoot and the coverage (expressed as a percentage of leaf surface) of each morphological group which was estimated with a binocular lens, then carefully scraped with a razor blade (Libes, 1986). Epiphytes and scraped leaves were oven-dried at $60{ }^{\circ} \mathrm{C}$ for $48 \mathrm{~h}$ before weighing (Alcoverro et al., 1997; Lepoint et al., 1999).

\subsection{Data analysis}

Multivariate analysis (MPMANOVA) was used to test the hypothesis that the structure of epiphytic assemblages differed between disturbed and control locations and to evaluate variability at different spatial scales (Anderson, 2001). The analysis consisted of a 6-way model with sites (three levels) being nested within locations (two levels), subsites (two levels) being nested within sites, plots (three levels) being nested within subsites, quadrats being nested within plots and sub-quadrats (four levels) being nested within quadrats. Sites, 
1 subsites, plots and quadrats were random whereas the contrast of disturbed versus control and

2 the disturbed were fixed. All data were transformed to $\ln (x+1)$ to remove heterogeneity of

3 variances (after Cochran's $C$-test). SIMPER analysis (Clarke, 1993) was used to identify the

4 percentage contribution of each species to the Bray-Curtis dissimilarity between the average

5 of the disturbed and the control locations. A two-dimensional nMDS (non-metric

6 multidimensional scaling), based on the centroids of the sites of the four locations, was used

7 for a graphical representation of the data for leaf epiphytic assemblages.

8 Variance components of all assemblages were calculated for each location and for all spatial scales. A discriminant analysis was used for classifying the different meadows into one among possible $K$ classes. These classes were identified by linear combinations of the

11 variables maximizing the homogeneity of each class. The test Wilks' lambda was employed to test whether there are differences between the means of identified groups of subjects among a combination of dependent variables.

Epiphyte biomass was standardized by shoot biomass to be able to compare epiphyte load among locations. This is necessary because a significant positive correlation was found between epiphyte biomass and leaf biomass (Fig. 2), allowing us to express epiphyte biomass as $g_{d w}$ epiphytes $/ g_{d w}$ of leaves. Differences in epiphytic biomass and the percentage cover of the main phyla or morphological groups were analyzed through 6-way ANOVA with the same factors and levels used in the multivariate analysis. Student-Newman-Keuls (SNK) test was employed for a posteriori multiple comparisons of means.

\section{3. Results}

22 A total of 49 taxa were identified in the epiphyte assemblages of control locations: 20

23 Macroalgae (11 Rhodophyta, 6 Cyanobacteria, 2 Chlorophyta, 1 Heterokontophyta), 11

24 Bryozoa, 9 Cnidaria (Hydrozoans), 3 Annelida, 2 Tunicata and 3 Porifera. A total of 32 taxa 25 were identified in the epiphyte assemblages of disturbed locations: 13 Macroalgae (7 
1 Rhodophyta, 4 Cyanobacteria, 1 Chlorophyta, 1 Heterokontophyta), 9 Bryozoa, 8 Cnidaria

2 (Hydrozoans), 1 Annelida and 1 Tunicata (Appendix 1). In control locations, leaf assemblages

3 were dominated by filamentous algae belonging to the genera Polysiphonia, Ceramium and

4 Antithamnion; common algal species were also present such as Dasycladus vermicularis,

$5 \quad$ Cladophora sp., Griffithsia opuntoides, Neomonospora sp. and Laurencia obtusa. Among

6 animals, the Bryozoans Alcyonidium and Electra Posidoniae dominated the community. The

7 Tunicata Botryllus schlosseri and Clavelina lepadiformis were numerically dominant. Among

8 the Cnidaria the most abundant species were Dynamina cavolinii, Monotheca sp. and

9 Aglaophenia sp. For encrusting Annelida the genus Spirorbis was the dominant genus, and for the Porifera the genus Ircinia dominated the Porifera assemblage. In disturbed locations, leaf assemblages were dominated by filamentous algae belonging to genera Antithamnion and Polysiphonia; other common algal species were also present such as Laurencia obtusa, dictyota dichotoma and Ceramium gracillimum. Among Bryozoa the genera Alcyonidium, Scrupocellaria and Bowerbankia were the most abundant. The Cnidaria Dynamena and Obelia were the most abundant genera. For the encrusting Annelida, the genus Spirorbis dominated the assemblage.

There was a difference between the two disturbed locations; the location Ghannouch was more affected than the location Zarrat, the number of species and the mean percentage cover were reduced for the majority of taxa. We noted the absence of Aetea truncata, Micropora complanata. Filamentous algae, namely Ceramium tenuissimum, Neomonospora sp. and 21 Dasya sp. were absent in the location of Ghannouch.

22 The high mean value of shoot density $\left(1022 \pm 54.23\right.$ shoot $\left.\mathrm{m}^{-2}\right)$ was recorded in the site 1 of 23 Hassar location (C1), whereas the lowest mean value $\left(119.5 \pm 17.67\right.$ shoot $\left.\mathrm{m}^{-2}\right)$ has been 24 detected in site 1 of Ghannouch location (D1) (Fig. 3). The lowest mean value of the leaf 25 surface area $\left(205.28 \pm 5.56 \mathrm{~cm}^{2}\right.$ shoot $\left.^{-1}\right)$ was recorded in the site 1 of the location Ghannouch 
1 (D1), whereas the hightest mean value $\left(467.28 \pm 5.82 \mathrm{~cm}^{2}\right.$ shoot $\left.^{-1}\right)$ was detected in the site 2

2 of the location Ghannouch (D1) (Fig. 4).

3 The hightest mean value of leaf length $(59.68 \pm 7.87 \mathrm{~cm})$ was recorded in the site $\mathrm{b}$ of the

4 control location Hassar (C1), whearas le lowest mean value $(29.2 \pm 4.87 \mathrm{~cm})$ was observed in

5 the site a of the disturbed location Ghannouch (D1) (Fig. 5).

6 ANOVA analysis showed that for density, leaf surface area and leaf length there was a

7 significant difference between (i) locations and (ii) between the contrast 'disturbed vs.

8 control' locations. For leaf surface area and leaf length, no significant difference could be

9 detected in the disturbed and the control locations separately. The difference was not

10 significant for shoot density among the control locations (Table 1). The disturbed location D1

11 has a lower mean epiphyte biomass ( $g_{d w}$ epiphytes $/ g_{d w}$ of leaves) than the location D2; this

12 value ranging between $0.02 \pm 0.07$ and $0.1 \pm 0.08 \mathrm{~g}_{\mathrm{dw}}$ epiphytes $/ \mathrm{g}_{\mathrm{dw}}$ of leaves at D1, and

13 between $0.25 \pm 0.07$ and $0.38 \pm 0.09 \mathrm{~g}_{\mathrm{dw}}$ epiphytes $/ \mathrm{g}_{\mathrm{dw}}$ of leaves in the location $\mathrm{D} 2$. In the

14 control location $\mathrm{C} 1$, the mean epiphyte biomass varied between $0.46 \pm 0.01$ and $0.63 \pm 0.03$

$15 \mathrm{~g}_{\mathrm{dw}}$ epiphytes $/ \mathrm{g}_{\mathrm{dw}}$ of leaves and between $0.33 \pm 0.17$ and $0.38 \pm 0.19 \mathrm{~g}_{\mathrm{dw}}$ epiphytes $/ \mathrm{g}_{\mathrm{dw}}$ of

16 leaves in the location C2 (Fig. 6).

17 Epiphyte biomass vs. leaf biomass displayed a fairly similar relationship in all locations, 18 suggesting that the leaf biomass pattern and hence the leaf surface availability was an 19 important factor governing the epiphytic biomass pattern as also reported by Borowitzka et al. 20 (2006) (Fig. 2). The two control locations C1 and C2 had the upper slope whereas the 21 disturbed locations present the lower what strongly suggests that anthropogenic disturbance 22 affects epiphyte load (Test of homogeneity of slope between control and disturbed locations; $\left.23 \mathrm{~F}_{(\mathrm{n}=3)}=430.07 ; \mathrm{p}=0.00002\right)$. Analyses of variance indicate a wide variability in the epiphytic 24 biomass among locations, sites, subsites and quadrats, whereas variation at the scale plot was 25 insignificant (Table 2). Variation between the two disturbed locations was important for both 
1 the largest and the smallest scales (quadrat), whereas significant difference was detected only

2 at the subsite and quadrat scale for the control locations. The structure of epiphytic

3 assemblage of leaves differed between the contrast of disturbed vs. control locations (Table

4 3), while no significant difference was observed among disturbed and control location

5 separately. Significant difference was observed in particular at the smallest scales plots and

6 quadrats. Epiphytes were generally abundant on leaves of P. oceanica (Fig. 7). Algae,

7 bryozoans and encrusting Annelida were common and abundant at all locations. Also

8 hydrozoans were widespread, but their percentage cover was generally low. The two

9 disturbed meadows were different from each other with an extra variability in percentage

10 covered in hydrozoans. Four morphological groups of organisms were sufficiently abundant

11 to be included in univariate analyses. For example, and concerning the percentage cover of

12 filamentous algae and hydrozoans, we recorded a significant difference between (i) locations when considered separately and between (ii) the contrast 'disturbed vs. control locations'. For encrusting Annelida a significant difference was detected only for the scale locations when considered separately, whereas, no significant difference was found for the contrast 'disturbed vs. control locations'. For bryozoans, there was no significant difference between these two scales (Table 4). On a scale site, a significant variability was detected for encrusting Annelida. At the scale subsite, a significant variability was detected for algae, whereas at the scale plot, variability was detected for all parameters. For the scale quadrat, a difference was significant for all variables but no difference was found between the percentage covers of disturbed and 21 control locations. nMDS ordination of leaf assemblages at the four locations showed a clear separation between the centroids based on sites of each control and disturbed locations (Fig. 8). The species responsible for the difference between disturbed and control locations changed. For example, 
1 tenuissimum and Ceramium codii, the bryozoans such as Micropora complanata and the

2 hydrozoan Dynamena cavolinii increased on leaves in the control locations, though some

3 species showed similar trends in these locations (Table 5).

4 Biomass, epiphytic leaf assemblages and the four abundant morphological groups of epiphyte

5 displayed different responses to the spatial variability among different scales at the disturbed

6 and the control locations (Table 6). Variance components indicated that most of the variability

7 occurred not only at the plot scale but also between locations and quadrats, with the exception

8 of biomass that displayed larger variation at the quadrat scale in disturbed locations.

9 Discriminate analysis, for both disturbed and control locations showed that there was a 10 strongly significant variation including all the factors of the P. oceanica meadows. Wilks' 11 lambda showed a high variability between locations for biomass, hydrozoans and density, and 12 high variability within locations especially for bryozoans (Table 7).

The projection on the first factorial design crossing the first two factorial discriminant axes corresponding to the first two discriminating linear functions as in table 8 , allows a description and a classification of the characterized variables (Fig. 9). The first axis shows discrimination between the two control and the two disturbed locations. The second axis divides locations in three groups: the control location $\mathrm{C} 1$, the crossing of the two disturbed locations, and the control location C2.

\section{Discussion}

The multivariate analysis illustrates a decrease in seagrass vitality (i.e. shoot density, leaf surface area and leaf length) in disturbed versus control locations, thus indicating the inability of disturbed meadows to withstand increasing urban interferences. Cancemi et al. (2003) and Balestri et al. (2004) reported that the decline of the phenologic parameters used to assess the seagrass bed vitality among the disturbed locations they sampled is function of the distance from the disturbance source as compared to control locations. In fact, the mean biomass in the 
1 inner Ghannouch location (D1) was lower than that recorded close to sewage outlet at Zarrat

2 location (D2). Similar results were reported by others (Short and Wyllie-Echeverria, 1996;

3 Leriche et al., 2006). We suspect the water column stability and the quality of sewage as

4 probably being the most important factor affecting the growth of $P$. oceanica in the coastal

5 disturbed area of the Gulf of Gabes. This is supported by at least two observations. First, the

6 disturbed locations D1 and D2, which have a muddy bottom, were mechanically turbulent

7 from the constant input of sewage outlet, conveying uniformity throughout the shallow water

8 column (Soussi and Mammoun, 1992; Zaouali, 1993), and therefore probably reducing leaf

9 photosynthetic activity (Mascaro et al., 2009). Decreases in shoot density and leaf length

10 related to decreases in light environment have already been reported from inner disturbed

11 locations (Ruiz and Romero, 2003). In contrast, Giovannetti et al. (2006) found no difference

12 in the shoot density, the Conservation Index and the epiphyte coverage between the control (marine protected area) and the disturbed (urbanized area) locations examined in their study.

Only a shift in the epiphyte species composition was observed in the urban meadows

subjected to the increase of the sewage outfalls during summer, which showed a considerable development of the brown algae. Indeed, Terrados et al. (2008) found no difference in shoot density between the control and the disturbed locations that they sampled. However, these authors studied locations that received inputs of nutrients and organic matter from only the resident population (Giovannetti et al., 2006) and park visitors (Terrados et al., 2008), whereas the Gulf of Gabes is exposed to a plethora of toxic inputs. For example, studies here 21 have reported high phosphogypsum concentration $\left(10 \mathrm{~g} \mathrm{l}^{-1}\right)$ at the sewage outlet, which spread over more than $60 \mathrm{~km}^{2}$ (Bejaoui et al., 2004). Dissolution of phosphogypsum was carried out by releasing cadmium and fluorine in sea water (Bejaoui et al., 2004), and cadmium has also been shown to be toxic to clams in the Gulf of Gabes (Hamza-Chaffai et al., 1999; Smaoui- 
1 healthy and no death was observed (Hattour et al., 1998; Ramos-Espla et al., 2000; Ben

2 Brahim et al., 2007). Also, since $P$. oceanica is very sensitive to low salinity in Tunisian

3 coastal regions such as the Gulf of Tunis (Northern Tunisia) (Ben Alaya, 1972), fresh waters

4 from sewage may also have lowered water salinity, thus affecting meadow growth too, but to

5 a lesser extent.

6 In terms of epiphytic leaf biomass, we also found the lowest mean biomass at the inner

7 disturbed Ghannouch location (D1). As previously mentioned for the meadow biomass, increases in water turbidity in disturbed locations are also detrimental to leaf epiphytic biomass since light is restricted (Cebrian et al., 1999). A similar general loss of epiphyte biomass and the regression of $P$. oceanica meadow according to disturbance level has also

11 been reported (Cambrige and McComb, 1984; Guidetti, 2001; Piazzi et al., 2004). In addition, macrograzers are known to feed preferentially on leaf tips where maximum epiphyte biomass is reached (Alcoverro et al., 1997; Ruiz and Romero, 2003; Peterson et al., 2007). This may have accounted, at least partially, for the natural loss of the epiphyte biomass both in disturbed and control locations in the Gulf of Gabes. This decrease in epiphyte biomass was also associated with a reduction of species sharing the epiphyte total biomass (49 species in disturbed location vs 32 species in control locations, see Appendix). Our findings are also supported by those of Mannino et al. (2010) who found a well-structured algal assemblage close to the sea (with low anthropogenic pressure) compared to the locations subjected to human disturbance. We, therefore, propose that in the Gulf of Gabes the spectrum of existing conditions was narrow and thus unfavorable for the coexistence of a high number of species. This is most likely due to toxicity from several compounds such as Cd (10-15 ppm, Soussi et al., 1992) and, as previously mentioned, phosphogypsum with a sedimentary section reaching $50 \mathrm{~cm}$ in Ghannouch location. In addition, concentrations in hydrocarbon were relatively high (between $882 \mu \mathrm{g} \mathrm{g}^{-1}$ and $4087 \mu \mathrm{g} \mathrm{g}^{-1}$ ) compared to those recorded from other coastal 
1 Mediterranean sediments (Zaghden et al., 2005). The spatial distribution of these polluting

2 elements is favored by dominant winds (west-east in summer and north-east and south-west in

3 winter) which permanently induced not only the mixing of sediment but also the

4 remobilization of the surface deposits (Soussi et al 1992). Others have also reported a

5 decrease in the vitality of the Posidonia meadow due to trace metal pollution (Pergent-Martini

6 et Pergent, 2000; Ben Chikha, 2009). Furthermore, animals on leaves exhibited different

7 responses to disturbance. For example, encrusting Annelida and Bryozoa displayed a reduced amount of variation in mean cover percentage at large spatial scales; in fact, the increase of the relative dominance in mean cover near the sewage outlet indicates a functional change in the assemblage related with the increase of the trophic component of micropredators

11 (Fraschetti et al., 2006). On the other hand, the sewage causes a significant decrease in terms of mean cover of Hydrozoans as previously reported by Cifuentes et al. (2007). The hydrozoan Gonothyraea gracilis and the two bryozoans Amathia lendigera and Beania hirtissima (Bryozoa) were presumably the most sensitive species to environmental stress as they were absent in the disturbed locations. We infer that this decrease is probably related to the water turbulence close to the discharge which affected the availability of potential preys such as zooplankton and particulate matter (Wahl, 1989; McKinney and Jackson, 1989; Ben Brahim et al., unpublished). In addition, bryozoans and hydrozoans showed different behavioral patterns related to the degree of disturbance, with bryozoans seeming more adapted than hydrozoans to increased disturbance (McKinney and Jackson, 1989). Obviously,

21 further studies are needed, for example by comparing the response of different epiphytes taxa, in order to elucidate the resilience of each group of epiphytes against disturbance levels and their strategy facing disturbed conditions. The present study showed that the variation in both the spatial pattern and abundance of macroalgal species, rather than their presence/absence, are indicative of disturbance. For example, the assemblage of epiphytic algae dominated by 
1 the Rhodophyta (order Ceramiales) tends to decrease in the two disturbed locations D1 and

2 D2. In this context, filamentous algae, especially the Ceramiales, may be considered the most

3 sensitive to disturbance. In other Mediterranean regions, Dictyotales were the dominant

4 species and grew abundantly in the disturbed sampled areas (Balata et al., 2007). On the other

5 hand, our results showed that the decrease of Ceramiales algae was paralleled with the

6 decrease of the green algae Dasycladus vermicularis, the cyanobacteria Lyngbia sp., Rivularia

7 sp., Gloeotrichia sp., Phormidium sp. and the red algae Dasya sp., Griffithsia sp. and

8 Pleonosporium sp., a decrease also paralleled with increases of anthropogenic disturbance.

9 Brown algae such as Myrionema orbiculare and Giraudia sphacelarioides are considered

10 characteristic of epiphyte community of $P$. oceanica leaves and have been already reported

11 along the northern Tunisian coast (Ribera et al., 1992). In many Mediterranean regions, $M$.

12 orbiculare was abundant (Giovannetti et al., 2006; Pardi et al., 2006; Sliskovic et al., 2010).

13 However, along the Tunisian coast this taxon was detected only in Bechateur which is located

14 in northern Tunisia (Menez and Mathieson, 1981). In the present study (southern Tunisia)

15 brown algae such as $M$. orbiculare, G. sphacelarioides were absent and only the species

16 Dictyota dichotoma was recorded. We infer that this absence might be related to the high

17 level of disturbance in the Gulf of Gabes. Our suggestion may be supported by the study of

18 Giovannetti et al. (2006) at Prelo cove in the Ligurian Sea (NW Mediterranean Sea) showing

19 that some brown algae such as Myrionema orbiculare, Giraudia sphacelarioides and

20 Fenestrulina johannae did not play a significant role in the epiphytic community structure,

21 whereas some Rhodophyta such as Hydrolithon-Pneophyllum spp. were the main epiphytes

22 that were present throughout the year at all stations. In control locations, leaf epiphytes

23 biomass of $P$. oceanica were most variable at the small scales investigated (among plots),

24 whereas variation at the intermediate scale (among sites, subsites) was negligible. In this

25 study, hierarchical sampling designs enabled an identification of homogeneity of epiphyte 
1 assemblage distribution for the majority of functional groups and biomass among the scale

2 site $(500-600 \mathrm{~m})$, while heterogeneity is displayed at large scales among regions and at small

3 scales among plots. Our study supports the results of Pardi et al. (2006), and Piazzi et al.

4 (2004), in terms of variability of epiphyte load on Posidonia oceanica which was greatest at

5 the extremes of the spatial extents they investigated, with patchiness greatest at the among-

6 shoot level (i.e. within quadrats), and at sites separated by a few hundred meters. Moore and

7 Fairweather (2006) and Balata et al. (2007) also considered that the epiphytes biomass within

8 the $100 \mathrm{~m}$ long transect sampled was homogenous, and more generally, Jernakoff and Neilsen

9 (1997) and Balestri et al. (2004) indicated that patchiness in epiphytes as well as in seagrass

10 morphology is significant over a range of scales (typically $\mathrm{cm}$ to $\mathrm{km}$ ).

11 5. Conclusion

12 Our study illustrated a spatial variability related to anthropogenic disturbance for (i) the 13 phenologic parameters of the plant host $P$. oceanica, such as shoot density, leaf length and 14 leaf surface area in the disturbed locations, for (ii) the mean percentage cover of targeted organisms and for (iii) the epiphytic biomass on leaves of $P$. oceanica.

The hierarchical sampling designs used in this study similarly to other investigations dealing with the spatial structuring of epiphytes-seagrass relations, pointed out a homogeneity in the distribution of epiphyte assemblages for the majority of functional groups and biomass among the scale site (500-600 m transect) while a heterogeneity was displayed at large scales among regions and at small scales among plots. Seagrass beds separated by few hundred of meters in

21 both disturbed and control locations will apparently be subjected to unique environmental conditions resulting in equally epiphytic leaves biomass and assemblages. P. oceanica meadow and its associated epiphytes appear to be strongly affected by human pressure in the Gulf of Gabes through sewage outlet (this study), in addition to other disturbances such as trawling, mooring, fish farming and coastal pollution. The regression trend will significantly 
1 increase unless there is efficient implementation of legal protection along with a reduction in

2 human interference. While restrictions on trawling have been introduced in Tunisia, this

3 practice being responsible for the loss of about $80 \%$ of the surface area of seagrass meadows

4 in the Gulf of Gabes (Zaouali, 1992), the legislation is not respected. In a recent review, many

5 authors regretted the lack of data in some Mediterranean regions, particularly indicating the

6 urgent need for studies on P. oceanica in North Africa (Ruiz et al., 2009). We, thus, believe

7 that our data may be, on a North African scale, not only worthwhile but also useful in

8 initiating other investigations. For example, the construction of "matte" by $P$. oceanica, a

9 feature unique among Mediterranean seagrasses and which may be useful for assessing the

10 regression of $P$. oceanica (Leriche et al., 2004; Boudouresque et al., 2009), should be further

11 addressed. Finally, it is urgent to propose the best management plans to save the remaining

$1220 \%$ of $P$. oceanica in the Gulf of Gabes and its associated epiphytes which have been

13 reported to be among the most productive marine and terrestrial ecosystems (Duarte and

14 Chiscano, 1999).

\section{6. Acknowledgements}

16 This study was conducted by Mounir Ben Brahim in the framework of his $\mathrm{PhD}$ and supported

17 by grants from by JICA (Japan International Cooperation Agency) and ESREB project (Étude

18 des Stocks et des Ressources Exploitables des Bivalves). It was conducted as part of a

19 collaborative project between the INSTM (Institut National des Sciences et Techniques de la

20 Pêche), the Faculty of Sciences of Sfax (Tunisia) and the University of Franche-Comté

21 (Chrono-Environnement, UMR CNRS 4269). The authors wish to thank the two reviewers for

22 helpful suggestions which improved our contribution. 


\section{List of figures:}

Figure 1. Geographical map focussing on sampling locations in the Gulf of Gabes.

Figure 2. Leaf biomass vs. epiphyte biomass $\left(\mathrm{g}_{\mathrm{dw}}\right.$ leaf $\left.^{-1}\right)$ for disturbed (D) and control (C) locations.

Figure 3. Average \pm SD values of the shoot density at the control $(\mathrm{C} 1, \mathrm{C} 2)$ and disturbed $\mathrm{D} 1$, D2) locations with the three nested sites $\mathrm{a}, \mathrm{b}$ and $\mathrm{c}$.

Figure 4. Average \pm SD values of the leaf surface area at the control (C) and disturbed (D) locations with the three nested sites $\mathrm{a}, \mathrm{b}$ and $\mathrm{c}$.

Figure 5. Average \pm SD values of leaf length at the control (C) and disturbed (D) locations with the three nested sites $\mathrm{a}, \mathrm{b}$ and $\mathrm{c}$.

Figure 6. Average $\pm \mathrm{SD}$ values of the mean biomass of leaf epiphytes of $P$. oceanica at the control (C) and disturbed (D) locations with the three nested sites a, b and c.

Figure 7. Mean percentage cover of the main epiphyte groups at the control and disturbed locations with the three nested sites a, b and c. (C1: Hassar; D1: Ghannouch; D2: Zarrat and C1: Ajim).

Figure 8. nMDS showing the dissimilarity among centroids of sites of epiphytic assemblages on leaves. Ghannouch: D1 $\diamond$, Zarrat: D2 , Hassar: $\mathrm{C} 1$, Ajim: C2. $\square$ Figure 9. Global projection on the first factorial design discriminating of variables and group centroids. 


\section{References}

2 Alcoverro, T., Duarte, C.M., Romero, J., 1997. The influence of herbivores on Posidonia

3 oceanica epiphytes. Aquatic Botany 56, 93-104.

4 Anderson, M.J., 2001. A new method for non-parametric multivariate analysis of variance.

5 Austral Ecology 26, 32-46.

6 Armitage, A. R., Frankovich, T. A., Fourqurean, J. W., 2006. Variable responses within

7 epiphytic and benthic microalgal communities to nutrient enrichment. Hydrobiologia 569, $8 \quad 423-35$.

9 Balata, D., Nesti, U., Piazzi, L., Cinelli, F., 2007. Patterns of spatial variability of seagrass epiphytes in the north-west Mediterranean Sea. Marine Biology 151, 2025-2035.

Balata, D., Bertocci, I., Piazzi, L., Nesti, U., 2008. Comparison between epiphyte assemblages of leaves and rhizomes of the seagrass Posidonia oceanica subjected to different levels of anthropogenic eutrophication. Estuarine, Coastal and Shelf Science 79, 533-540.

Balestri, E., Benedetti-Cecchi, L., Lardicci, C., 2004. Variability in patterns of growth and morphology of Posidonia oceanica exposed to urban and industrial wastes: contrasts with two reference locations. Journal of Experimental Marine Biology and Ecology 308, 1-21.

Bejaoui, B., Raïs, S., Koutitonsky, V., 2004. Modélisation de la dispersion du phosphogypse dans le Golfe de Gabès. Bulletins de l'Institut Océanographique et de Pêche de Salammbô. 31, 103-109.

Bel Hassen, M., Drira, Z., Hamza, A., Ayadi, H., Akrout, F., Messaoudi, S., Issaoui, H., 21 Aleya, L., Bouaïn, A., 2009. Phytoplankton dynamics related to water mass properties in the 22 Gulf of Gabes: Ecological implications. Journal of Marine Systems 75, 216-226. Ben Alaya, H., 1972. Répartition et conditions d'installation de Posidonia oceanica Delile et Cymodocea nodosa Ascherson dans le Golfe de Tunis. Bulletins de l'Institut 
1 Ben Brahim, M., Hiroaki, T., Hamza, A., 2007. Proceedings of the third Mediterranean

2 symposium on marine vegetation, Marseille, $300 \mathrm{pp}$.

3 Ben Chikha, M., 2009. Evaluation de la réaction de la Magnoliophyte marine Posidonia

4 oceanica (L.) Delile, vis-à-vis de la contamination mercurielle dans les côtes nord de la ville 5 de Sfax. Master, Université de Sfax, Tunisie, 80 pp.

6 Ben Mustapha, K., 1995. The Gulf of Gabes: A case study in the Mediterranean decline in

7 Fishing out the Mediterranean. $21^{\text {st }}$ session of the G.F.C.M, Spain, Greenpeace International 8 (Eds), Netherlands, 8-9.

9 Ben Mustapha, K., Zarrouk, S., Souissi, A., El Abed, A., 2003. Diversity of Tunisian 10 demosponges. Bulletins de l'Institut Océanographique et de Pêche de Salammbô 30, 55-78.

11 Boudouresque, C.F., Bernad, G., Pergent, G., Shili A., Verlaque M., 2009. Regression of 12 Mediterranean seagrasses caused by natural processes and anthropogenic disturbances and stress: a critical review. Botanica Marina 52, 395-418.

Buia, M.C., Zupo, V., Mazzella L., 1992. Primary production and growth in Posidonia oceanica. P.S.Z.N. Marine Ecology 13, 2-16.

Cambrige, M.L., McComb, A.J., 1984. The loss of seagrasses in Cockburn Sound. Western

17 Australia. I. the time course and magnitude of seagrass decline in relation to industrial development. Aquatic Botany 20, 229-243.

Cancemi, G., De Falco, G., Pergent, G., 2003. Effects of organic matter input from a fish

22 Cebrian, J., Enriquez, S., Fortes, M., Agawin, N., Vermaat, J.E., Duarte, C.M., 1999. 23 Epiphyte accrual on Posidonia oceanica (L.) Delile leaves: implications for light absorption. 
1 C.G.P. 1996. Annuaire des statistiques des pêches en Tunisie. Ministère de l'agriculture,

2 Tunisie.

3 Chapman, M.G., Underwood, A.J., Skilleter, G.A., 1995. Variability at different spatial scales

4 between a subtidal assemblage exposed to the discharge of sewage and two control

5 assemblages. Journal of Experimental Marine Biology and Ecology 189, 103-122.

6 Cifuentes, M., Kamlah, C., Thiel, M., Lenz, M., Wahl, M., 2007. Effects of temporal

7 variability of disturbance on the succession in marine fouling communities in northern-central

8 Chile. Journal of Experimental Marine Biology and Ecology 352, 280-294.

9 Clarke, K.R., 1993. Non-parametric multivariate analyses of changes in community structure. Australian Journal of Ecology 18, 117-143.

Delgado, O., Ruiz, J., Pérez, M., Ballesteros, E., 1999. Effects of fish farming on seagrass (Posidonia oceanica) in a Mediterranean bay: seagrass decline after organic loading cessation. Oceanologica Acta 22, 109-117.

Drira, Z., Hamza, A., Bel Hassen, M., Ayadi, H., Bouaïn, A., Aleya, L., 2008. Dynamics of dinoflagellates and environmental factors during the summer in the Gulf of Gabes (Tunisia, Eastern Mediterranean Sea). Scientia Marina 72, 59-71.

Drira, Z., Bel Hassen, M., Hamza, A., Rebai, A., Bouaïn, A., Ayadi, H., Aleya, L., 2009. Coupling of phytoplankton community structure to nutrients, ciliates and copepods in the Gulf of Gabes (South Ionian Sea, Tunisia). Journal of the Marine Biological Association, UK. 1-11, doi: 10.1017/S002531540900023.

Duarte, C. M., Borum, J., Short, F. T., Walker, D. I., 2004. Seagrass ecosystems: their global status and prospects. In Aquatic Ecosystems: Trends and Global Prospects, pp. 281-294. Edited by N. V. C. Polunin. Cambridge: Cambridge University Press. 
1 Fourqurean, J. W., Muth M. F. A., Boyer, J. N., 2010. Epiphyte loads on seagrasses and

2 microphytobenthos abundance are not reliable indicators of nutrient availability in

3 oligotrophic coastal ecosystems. Marine Pollution Bulletin 60, 971-983

4 Frankovich, T. A., Armitage, A. R., Wachnicka, A. H., Gaiser, E. E and Fourqurean J. W.

5 2009. Nutrient effects on seagrass epiphyte community structure in Florida Bay. Journal of

6 Phycology 45, 1010-1020.

7 Fraschetti, S., Gambi, C., Giangrande, A., Musco, L., Terlizzi, A., Danovaro, R., 2006.

8 Structural and functional response of meiofauna rocky assemblages to sewage pollution.

9 Marine Pollution Bulletin 52, 540-548.

10 Gambi, M.C., Giangrande, A., Chessa, L.A., Manconi, R., Scardi M., 1989. Distribution and

11 ecology of Polychaetes in the foliar stratum of a Posidonia oceanica bed in the bay of Porto

12 Conte (N.W. Sardinia). International Workshop on Posidonia beds. édit., GIS Posidonie publ.

13 Fr. 2, 175-187.

14 Giovannetti, E,. Montefalcone, M., Bianchi, C.N., Morri, C., Albertelli, G., 2006. Structural variability of the epiphytic community in a Posidonia oceanica meadow (Ligurian sea, NW mediteranean). Biologia Marina Mediterranea 13, 145-148.

Giovannetti, E., Montefalcone, M., Morri, C., Bianchi, C.N., Albertelli, G., 2010. Early warning response of Posidonia oceanica epiphyte community to environmental alterations (Ligurian Sea, NW Mediterranean). Marine Pollution Bulletin 60, 1032-1039.

Guidetti, P., 2001. Detecting environmental impacts on the Mediterranean seagrass Posidonia oceanica (L.) Delile: the use of reconstructive methods in combination with "beyond BACI" designs. Journal of Experimental Marine Biology and Ecology 260, 27-39.

Hamza, A., Bradai, M. N., Ghorbel, M., Abdelmoulah, A., 1995. New mentions of Caulerpa racemosa (Forsskal) J. Agardh in the Gabes Gulf (Tunisia). Bulletins de l'Institut Océanographique et de Pêche de Salammbô 22, 81-88. 
1 Hamza-Chaffai, A., Amiard, J.C., Cosson, R.P., 1999. Relationship between metallothionein

2 and metals in a natural population of clam Ruditapes decussates from Sfax coast, a non-linear

3 model using Box-Cox transformation. Comparative Biochemistry and Physiology 123, 153-

4163.

5 Hannachi, I., Drira, Z., Bel Hassen, M., Hamza, A., Ayadi, H., Bouain, A., Aleya, L., 2009.

6 Abundance and biomass of the ciliate community during a spring cruise in the Gulf of Gabes

7 (East Mediterranean Sea, Tunisia). Acta Protozoologica 47, 293-305.

8 Hattour, A., Ben Mustapha, K., El Abed, A., Chaouch, M., 1998. L'écosystème du golfe de

9 Gabès; dégradation de son couvert végétal et de sa pêcherie benthique. Bulletins de l'Institut

10 Océanographique et de Pêche de Salammbô 25, 5-40.

11 Hemminga, M., Duarte, C.M., 2000. Seagrass Biology. Cambridge, Univ, Press, 298 pp.

12 Jernakoff, P., Nielson, J., 1997. The relative importance of amphipod and gastropod grazers in 13 Posidonia sinuosa meadows. Aquatic Botany 56, 183-202.

14 Kchaou, N., Elloumi, J., Drira, Z., Hamza, A., Ayadi, H., Bouain, A., Aleya, L., 2009.

15 Distribution of ciliates in relation to environmental factors along the coastline of the Gulf of 16 Gabes, Tunisia. Estuarine, Coastal and Shelf Science 83, 414-424.

17 Kendrick, G. A., Burt, J. S., 1997. Seasonal changes in epiphyte macro-algae assemblages between offshore exposed and inshore protected Posidonia sinuosa Cambridge et Kuo seagrass meadows, Western Australia. Botanica Marina 40, 77-86.

Lavery, P., Vanderklift, M., 2002. A comparison of spatial and temporal patterns in epiphytic 21 macroalgal assemblages of the seagrasses Amphibolis griffithii and Posidonia coriacea. 22 Marine Ecology Progress Series 236, 99-112.

23 Lepoint, G., Havelange, S., Gobert, S., Bouquegneau, J.M., 1999. Fauna vs flora contribution 24 to leaf epiphytes biomass in a Posidonia oceanica seagrass bed (Revellata Bay Corsica). 25 Hydrobiologia 394, 63-67. 
1 Leriche, A., Boudouresque, C. F., Bernard, G., Bonhomme, P., Denis J., 2004. A one-century

2 suite of seagrass bed maps: can we trust ancient maps? Estuarine, Coastal and Shelf Science $359,353-362$.

4 Libes, M., 1986. Productivity-irradiance relationship of Posidonia oceanica and its epiphytes.

5 Aquatic Botany 26, 285-306.

6 Manninio, A. M., 2010. Temporal and spatial variation of the algal community in a southern

7 Mediterranean shallow system. Cryptogamie Algologie 31, 255-272.

8 Martínez-Crego, B., Prado, P., Alcoverro, T., Romero, J., 2010. Composition of epiphytic leaf

9 community of Posidonia oceanica as a tool for environmental biomonitoring. Estuarine,

10 Coastal and Shelf Science 88, 199-208.

11 Mascaro, O., T. Valdemarsen, M., Holmer, M., Perez., J. Romero., 2009. Experimental

12 manipulation of sediment organic content and water column aeration reduces Zostera marina

13 (eelgrass) growth and survival. Journal of Experimental Marine Biology and Ecology 373, 26-

1434.

15 Mazzella, L., Scipione, M.B., Buia, M.C., 1989. Spatio-temporal distribution of algal and 16 animal communities in a Posidonia oceanica (L.) Delile meadow. PSZNI. Marine Ecolgy 10, $17 \quad 107-131$.

18 McKinney, F. K and Jackson, J. B. C., 1989. Bryozoan evolution. Special Topics in 19 Palaeontology. Boston, MA: Unwin Hyman.

20 Menez, E.G., Mathieson, A.G., 1981. The Marine Algae of Tunisia. Smithsonian Institution $21 \quad$ Press. 58 pp.

22 Meric, S., Nicola, E. D., Iaccarino, M., Gallo, M., Gennaro, A. D., Morrone, G., Warnau, M., 23 Belgiorno, V., Pagano, G., 2005. Toxicity of leather tanning wastewater effluents in sea 24 urchin early development and in marine microalgae. Chemosphere 61, 208-217. 
1 Montefalcone, M., 2009. Ecosystem health assessment using the Mediterranean seagrass

2 Posidonia oceanica: a review. Ecological Indicators 9, 595-604.

3 Moore, T.N., Fairweather, P.G., 2006. Lack of significant change in epiphyte biomass with

4 increasing extent of measurement within seagrass meadows. Estuarine, Coastal and Shelf

5 Science $68,413-420$.

6 Neckles, H. A., Koepfler, E. T., Haas, L. W., Wetzel, R. L., Orth, R. J., 1994. Dynamics of 7 epiphytic photoautotrophs and heterotrophs in Zostera marina (eelgrass) microcosms: responses to nutrient enrichment and grazing. Estuaries 17, 597-605.

9 Nelson, T.A., Waaland, J.R., 1997. Seasonality of eelgrass, epiphyte, and grazer biomass and productivity in subtidal eelgrass meadows subjected to moderate tidal amplitude. Aquatic 11 Botany 56, 51-74.

Nesti, U., Piazzi, L., Balata, D., 2008. Variability in the structure of epiphytic assemblages of the Mediterranean seagrass Posidonia oceanica in relation to depth. Marine Ecology 30, 276287.

Pardi, G., Piazzi, L., Balata, D., Papi, I., Cinelli F., Benedetti-Cecchi, L., 2006. Spatial variability of Posidonia oceanica (L.) Delile epiphytes around the mainland and the islands of Sicily (Mediterranean Sea). Marine Ecology 27, 397-403.

Pergent-Martini, C; Pergent, G., 2000. Marine phanerogams as a tool in the evaluation of marine trace-metal contamination: an example from the Mediterranean. International Journal of Environment and Pollution 13, 1-6.

21 Peterson, B.J., Frankovich, T.A., Zieman, J.C., 2007. Response of seagrass epiphyte loading to field manipulations of fertilization. Gastropod grazing and leaf turnover rates. Journal of 23 Experimental Marine Biology and Ecology 349, 61-72.

24 Piazzi, L., Balata, D., Cinelli, F., 2002. Epiphytic macroalgal assemblages of Posidonia oceanica rhizomes in the western Mediterranean. European Journal of Phycology 37, 69-76. 
1 Piazzi, L., Balata, D., Cinelli, F., Benedetti-Cecchi, L., 2004. Patterns of spatial variability in

2 epiphytes of Posidonia oceanica. Differences between a disturbed and two reference 3 locations. Aquatic Botany 79, 345-356.

4 Prado, P., Farina, S., Tomas, F., Romero., J., Alcoverro, T., 2008. Marine protection and 5 meadow size alter fish herbivory in seagrass ecosystems. Marine Ecology Progress Series $6 \quad 371,11-21$.

7 Ramos-Espla, A., Ouergui, A., Bayle, J.T., Ben Mbarek, N., Fernanadez-Troquemada, Y., 8 Gallouza, S., Khidri, R., Sanchez-lizaso, J.L., Yamak, S., 2000. Contribution à la 9 caractérisation des herbiers à Posidonia oceanica (L.) Delile aux Iles Kerkennah (Est de la 10 Tunisie, Mediterranée orientale). Proceedings of The First Mediterranean Symposium on 11 Marine Vegetation 177-181.

12 Ribera, M.A., Gomez-Garreta, A., Gallardo, T., Cormaci, M., Furnari, G., Giaccone, G., 1992. Checklist of Mediterranean seaweed. I. Fucophyceae (Warming, 1884). Botanica

14 Marina 35, 109-130.

Ruiz, J.M., Romero, J., 2003. Effects of disturbances caused by coastal constructions on spatial structure, growth dynamics and photosynthesis of the seagrass Posidonia oceanica. Marine Pollution Bulletin 46, 1523-1533.

Saunders, J. E., Attrill, M. J., Shaw, S. M., Rowden, A. A., 2003. Spatial variability in the epiphytic algal assemblages of Zostera marina seagrass beds. Marine Ecology Progress Series 249, 107-115.

21 Sliskovic, M., Jelic-Mrcelic, G., Antolic, B., Anicic, I., 2010. The fouling of fish farm cage nets as bioindicator of aquaculture pollution in the Adriatic Sea (Croatia). Environmental and Monitoring Assessment doi: 10.1007/s10661-010-1402-y. of the clam Ruditapes decussatus exposed in situ to metal contamination and originating from 
1 the Gulf of Gabes, Tunisia. Bulletin of Environmental Contamination and Toxicology 7, 961-

2970.

3 Smaoui-Damak, W., Rebai, T., Berthet, B., Hamza-Chaffai, A., 2006. Does cadmium

4 pollution affect reproduction in the clam Ruditapes decussates? A one-year case study.

5 Comparative Biochemistry and Physiology, Part C 143, 252-261.

6 Soussi, N., Mammoun, B., 1992. Contribution à l'étude de la pollution marine dans le Golfe

7 de Gabès. Rapport de synthèse 50pp.

8 Terrados, J and Javier Medina Pons, F., 2008. Epiphyte load on the seagrass Posidonia

9 oceanica (L.) Delile does not indicate anthropogenic nutrient loading in Cabrera Archipelago

10 National Park (Balearic Islands, Western Mediterranean). Scientia Marina 72, 503- 510.

11 Trautman D. A., Borowitzka M. A., 1999. The distribution of the epiphytic organisms on

12 Posidonia australis and P. sinuosa, two seagrasses with differing leaf morphology. Marine

13 Ecology Progress Series 179, 215-229.

14 Underwood, A.J., 1994. On beyond BACI: sampling designs that might reliably detect

15 environmental disturbances. Ecological Application 4, 3-15.

16 Van der Ben, D., 1971. Les épiphytes des feuilles de Posidonia oceanica Delile sur les côtes

17 françaises de la Méditerranée. Mémoire de l'Institut Royal des Sciences Naturelles de 18 Belgique 168, 1-101.

19 Vanderklift, M., Lavery, P., 2000. Patchiness in assemblages of epiphytic macroalgae on 20 Posidonia coriacea at a hierarchy of spatial scales. Marine Ecology Progress Series 192, 127$21 \quad 135$.

22 Wahl, M., 1989. Marine epibiosis. I. Fouling and antifouling: some basic aspects. Marine 23 Ecology Progress Series 58, 175-189. 
1 Zaghden, H., Kallel, M., Louati, A., Elleuch, B., Oudot, J., Saliot, A. 2005. Hydrocarbons in

2 surface sediments from the Sfax coastal zone, (Tunisia) Mediterranean Sea. Marine Pollution

3 Bulletin 50, 1287-1294.

4 Zaouali, J., 1993. Les peuplements benthiques de la petite Syrte, Golfe de Gabès - Tunisie.

5 Résultats de la campagne de prospection du mois de juillet 1990. Marine Life 3, 47-60.

6

7

8

9

10

11

12 
Table 1. Analysis of variance on shoot density, leaf surface area and leaf length. Bold numbers indicate significant effects. C = control locations; $\mathrm{D}=$ disturbed locations.

\begin{tabular}{|c|c|c|c|c|c|c|c|c|c|c|}
\hline \multirow[b]{2}{*}{ Source of Variation } & \multirow[b]{2}{*}{ d.f } & \multicolumn{3}{|c|}{ Shoot density } & \multicolumn{3}{|c|}{ Leaf surface area } & \multicolumn{3}{|l|}{ Leaf length } \\
\hline & & MS & $\mathrm{F}$ & $P$ & MS & $\mathrm{F}$ & $\mathrm{P}$ & MS & $\mathrm{F}$ & $\mathrm{P}$ \\
\hline Locations $=\mathrm{L}$ & 3 & $2.6810^{7}$ & 176.90 & 0.00 & $1.0310^{6}$ & 11.71 & 0.00 & 9.31 & 8.25 & 0.00 \\
\hline Disturbed vs. Controls (DC) & 1 & $6.8810^{7}$ & 503.81 & 0.00 & $2.4410^{6}$ & 16.55 & 0.02 & 20.15 & 12.78 & 0.02 \\
\hline Among Disturbed (=D) & 1 & $1.1710^{7}$ & 63.28 & 0.00 & $5.5210^{5}$ & 4.579 & 0.10 & 0.07 & 0.06 & 0.82 \\
\hline Among Controls $(=\mathrm{C})$ & 1 & 215.90 & 0.002 & 0.97 & $1.0310^{5}$ & 1.868 & 0.24 & 7.71 & 7.46 & 0.05 \\
\hline Site (DC) & 4 & $1.3610^{5}$ & 6.19 & 0.03 & $14710^{5}$ & 9.46 & 0.01 & 1.57 & 0.17 & 0.94 \\
\hline Site (D) & 4 & $1.8510^{5}$ & 18.95 & 0.00 & $12010^{5}$ & 13.3 & 0.00 & 1.22 & 0.24 & 0.91 \\
\hline Site $(C)$ & 4 & $1.1810^{5}$ & 5.43 & $\mathbf{0 . 0 3}$ & 55474.20 & 7.71 & 0.02 & 1.03 & 0.22 & 0.92 \\
\hline Subsite (Site (DC)) & 6 & 22030.05 & 1.19 & 0.34 & 15550.04 & 3.879 & 0.01 & 9.46 & 3.66 & 0.01 \\
\hline Subsite (Site (D)) & 6 & 9767.25 & 0.97 & 0.47 & 9060.70 & 4.58 & 0.00 & 5.19 & 4.08 & 0.00 \\
\hline Subsite (Site (C)) & 6 & 21758.39 & 1.30 & 0.30 & 7192.68 & 3.56 & 0.01 & 4.68 & 3.17 & 0.02 \\
\hline Plot (subsite (Site (DC))) & 24 & 18454.41 & 0.82 & 0.70 & 4009.17 & 6.925 & 0.00 & 2.58 & 3.44 & 0.00 \\
\hline Plot (subsite (Site (D))) & 26 & 10079.36 & 0.45 & 0.99 & 1992.08 & 7.32 & 0.00 & 1.27 & 3.04 & 0.00 \\
\hline Plot (subsite (Site $(\mathrm{C}))$ ) & 26 & 16742.5 & 1.42 & 0.13 & 2020.14 & 6.39 & 0.00 & 1.48 & 3.82 & 0.00 \\
\hline Quadrat $(\operatorname{plot}(\operatorname{subsite}($ Site $(\mathrm{DC}))))$ & 72 & 22433.62 & 0.82 & 0.86 & 578.97 & 0.339 & 0.99 & 0.75 & 6.76 & 0.00 \\
\hline Quadrat (plot(subsite( Site (D)))) & 72 & 22550.45 & 12.38 & $\mathbf{0 . 0 0}$ & 271.83 & 0.802 & 0.86 & 0.42 & 3.78 & 0.00 \\
\hline Quadrat (plot(subsite $($ Site $(C))))$ & 72 & 11816.26 & 2.69 & 0.00 & 316.04 & 0.95 & 0.58 & 0.39 & 5.59 & 0.00 \\
\hline Residual & 432 & 3108.5 & & & 334.92 & & & 0.09 & & \\
\hline Residual D & 216 & 1820.99 & & & 339.03 & & & 0.11 & & \\
\hline Residual C & 216 & 4396.01 & & & 330.8 & & & 0.07 & & \\
\hline Transformation & & None & & & & None & & & $\operatorname{Ln}(x+1)$ & \\
\hline Cochran's C test & & $\mathrm{C}=0.05$, & & & & $\mathrm{C}=0.40$ & $<0.01$ & & $\mathrm{C}=0.288$, & ignificant \\
\hline
\end{tabular}


Table 2. Analysis of variance on the epiphytic biomass on the leaves of $P$. oceanica. Bold numbers indicate significant effects.

\begin{tabular}{lcccc}
\hline Source of Variation & d.f & MS & F & P \\
\hline Locations = L & 3 & $3.46 \times 10^{7}$ & 30.85 & $\mathbf{0 . 0 0}$ \\
$\quad$ Disturbed vs. Controls (DC) & 1 & $8.08 \times 10^{7}$ & 25.23 & $\mathbf{0 . 0 0}$ \\
$\quad$ Among Disturbed (=D) & 1 & $8.57 \times 10^{6}$ & 655.01 & $\mathbf{0 . 0 0}$ \\
$\quad$ Among Controls (=C) & 1 & $1.44 \times 10^{7}$ & 6.48 & 0.06 \\
& & & & \\
Site (DC) & 10 & $3.20 \times 10^{6}$ & 5.97 & $\mathbf{0 . 0 0}$ \\
Site (D) & 4 & 13097.61 & 0.25 & 0.89 \\
Site (C) & 4 & $2.23 \times 10^{6}$ & 2.17 & 0.19 \\
& & & & \\
Subsite (Site (DC)) & 12 & 537886.63 & 4.834 & $\mathbf{0 . 0 0}$ \\
Subsite (Site (D)) & 6 & 51026.48 & 1.94 & 0.11 \\
Subsite (Site (C)) & 6 & $1.0 \times 10^{6}$ & 5.22 & $\mathbf{0 . 0 0}$ \\
Plot (subsite (Site (DC))) & 48 & 111265.64 & 1.05 & 0.40 \\
Plot (subsite (Site (D))) & 24 & 26197.42 & 1.34 & 0.17 \\
Plot (subsite (Site (C))) & 24 & 196333.85 & 1.02 & 0.45 \\
& & & & \\
Quadrat (plot(subsite( Site (DC)))) & 144 & 105953.6 & 4.59 & $\mathbf{0 . 0 0}$ \\
Quadrat (plot(subsite( Site (D)))) & 72 & 19465.36 & 4.58 & $\mathbf{0 . 0 0}$ \\
Quadrat (plot(subsite( Site (C)))) & 72 & 192441.83 & 4.59 & $\mathbf{0 . 0 0}$ \\
& & & & \\
Residual & 648 & 23086.88 & & \\
Residual D & 324 & 4243.37 & & \\
Residual C & 324 & 41930.39 & & \\
\hline
\end{tabular}


Table 3. Non-parametric multivariate analysis of variance (NP-MANOVA) on epiphytic assemblage of Posidonia oceanica. Bold numbers indicate significant effects.

\begin{tabular}{lcccc}
\hline Source of Variation & d.f & MS & F & P \\
\hline Locations = L & 3 & 489.94 & 24.27 & $\mathbf{0}$ \\
$\quad$ Disturbed vs. Controls (DC) & 1 & 1412.48 & 64.55 & 0 \\
$\quad$ Among Disturbed (=D) & 1 & 52.46 & 3.44 & 0.137 \\
$\quad$ Among Controls (=C) & 1 & 4.88 & 0.19 & 0.682 \\
& & & & \\
Site (DC) & 10 & 21.88 & 1.173 & 0.391 \\
Site (D) & 4 & 15.23 & 0.46 & 0.762 \\
Site (C) & 4 & 25.14 & 5.761 & 0.03 \\
& & & & \\
Subsite (Site (DC)) & 12 & 18.66 & 0.855 & 0.595 \\
Subsite (Site (D)) & 6 & 32.96 & 1.16 & 0.361 \\
Subsite (Site (C)) & 6 & 4.36 & 0.29 & 0.937 \\
& & & & \\
Plot (subsite (Site (DC))) & 48 & 21.18 & $2.15 \times 10^{13}$ & $\mathbf{0}$ \\
Plot (subsite (Site (D))) & 24 & 28.47 & 0 & $\mathbf{0}$ \\
Plot (subsite (Site (C))) & 24 & 15.16 & 0 & $\mathbf{0}$ \\
& & & & \\
Quadrat (plot(subsite( Site (DC)))) & 144 & 0 & 0 & $\mathbf{0}$ \\
Quadrat (plot(subsite( Site (D)))) & 72 & 0 & 0 & $\mathbf{0}$ \\
Quadrat (plot(subsite( Site (C)))) & 72 & 0 & 0 & $\mathbf{0}$ \\
Residual & & & & \\
Residual D & 648 & 0 & & \\
Residual C & 324 & 0 & & \\
\hline
\end{tabular}


Table 4. Analysis of variance on mean percentage cover of epiphytes of Posidonia oceanica.

Bold numbers indicate significant effects.

\begin{tabular}{|c|c|c|c|c|c|c|c|c|c|c|c|c|c|}
\hline \multirow[b]{2}{*}{ Source of Variation } & \multirow[b]{2}{*}{ d.f } & \multicolumn{3}{|c|}{ Filamentous algae } & \multicolumn{3}{|c|}{ Bryozoans } & \multicolumn{3}{|c|}{ Hydrozoans } & \multicolumn{3}{|c|}{ Encrusting Annelida } \\
\hline & & $M S$ & $F$ & $P$ & $M S$ & $F$ & $P$ & $M S$ & $F$ & $P$ & $M S$ & $F$ & $P$ \\
\hline Locations $=\mathrm{L}$ & 3 & 43.014 & 10.5 & 0.004 & 0.11 & 0.06 & 0.986 & 147.13 & 12.08 & 0.002 & 64.1 & 4.83 & 0.033 \\
\hline Disturbed vs. Controls = DC & 1 & 104.59 & 19.6 & 0.001 & 0.2 & 0.1 & 0.755 & 395.59 & 29.12 & $\mathbf{0}$ & 44.75 & 1.78 & 0.211 \\
\hline Disturbed $=\mathrm{D}$ & 1 & 12.68 & 1.85 & 0.245 & 0.02 & 0.01 & 0.929 & 31.92 & 1.54 & 0.281 & 86.09 & 6.19 & 0.068 \\
\hline Controls $=\mathrm{C}$ & 1 & 8.812 & 7.87 & 0.049 & 0.08 & 0.03 & 0.864 & 8.12 & 2.44 & 0.194 & 59.74 & 4.85 & 0.092 \\
\hline Site $(\mathrm{L})=\mathrm{SL}$ & 8 & 4.07 & 0.46 & 0.861 & 2.53 & 1.8 & 0.173 & 12.18 & 1.75 & 0.183 & 13.28 & 2.59 & 0.067 \\
\hline Site $(\mathrm{DC})=\mathrm{SiDC}$ & 10 & 5.32 & 0.61 & 0.781 & 1.95 & 1.41 & 0.282 & 13.58 & 1.95 & 0.136 & 25.07 & 4.87 & 0.006 \\
\hline Site $(D)=\operatorname{SiD}$ & 4 & 6.83 & 0.46 & 0.759 & 2.43 & 0.95 & 0.495 & 20.61 & 2.25 & 0.178 & 13.9 & 1.94 & 0.222 \\
\hline Site $(C)=\operatorname{SiC}$ & 4 & 1.12 & 0.39 & 0.813 & 2.42 & 11.43 & 0.006 & 3.33 & 0.69 & 0.623 & 12.32 & 3.91 & 0.067 \\
\hline Subsite (SL) & 12 & 8.8 & 2.3 & 0.02 & 1.4 & 1.29 & 0.25 & 6.93 & 1.18 & 0.322 & 5.12 & 0.9 & 0.551 \\
\hline Subsite (SiDC) & 12 & 8.76 & 2.28 & 0.022 & 1.38 & 1.33 & 0.232 & 6.96 & 1.19 & 0.312 & 5.15 & 0.91 & 0.544 \\
\hline Subsite (SiD) & 6 & 14.62 & 2.56 & 0.046 & 2.55 & 1.67 & 0.17 & 9.12 & 1.17 & 0.351 & 7.14 & 0.82 & 0.567 \\
\hline Subsite (SiC) & 6 & 2.91 & 1.47 & 0.23 & 0.21 & 0.38 & 0.882 & 4.81 & 1.24 & 0.321 & 3.15 & 1.221 & 0.33 \\
\hline Plot ( Subsite (SL)) & 48 & 3.81 & 0 & $\mathbf{0}$ & 0 & 0 & 0 & 5.87 & 0 & $\mathbf{0}$ & 5.67 & 0 & $\mathbf{0}$ \\
\hline Plot (Subsite(SiDC)) & 48 & 3.83 & 1569.1 & $\mathbf{0}$ & 1.04 & 867.34 & $\mathbf{0}$ & 5.81 & 1346.47 & $\mathbf{0}$ & 5.65 & 2220.02 & $\mathbf{0}$ \\
\hline Plot (subsite(S(D)) & 24 & 5.69 & 1386.2 & $\mathbf{0}$ & 1.52 & 1456.2 & $\mathbf{0}$ & 7.75 & 1242.7 & $\mathbf{0}$ & 8.73 & 4416.98 & $\mathbf{0}$ \\
\hline Plot (subsite(SiC)) & 24 & 1.97 & 2528.35 & $\mathbf{0}$ & 0.55 & 409.47 & $\mathbf{0}$ & 3.87 & 1616.59 & $\mathbf{0}$ & 2.58 & 826.63 & $\mathbf{0}$ \\
\hline Quadrat(Plot(Subsite (SL))) & 144 & 0 & 0 & $\mathbf{0}$ & 0 & 0 & $\mathbf{0}$ & 0.001 & 0 & $\mathbf{0}$ & 0 & 0 & $\mathbf{0}$ \\
\hline Quadrat(Plot(Subsite(SiDC))) & 144 & 0.002 & 0.92 & 0.74 & 0.001 & 0.92 & 0.746 & 0.004 & 1.01 & 0.457 & 0.01 & 0.98 & 0.539 \\
\hline Quadrat(plot(subsite(S(D))) & 72 & 0.004 & 0.91 & 0.679 & 0.001 & 1 & 0.484 & 0.006 & 1 & 0.484 & 0.01 & 0.95 & 0.584 \\
\hline Quadrat(plot(subsite(S(D))) & 72 & 0.001 & 0.94 & 0.607 & 0.001 & 0.86 & 0.775 & 0.002 & 1.04 & 0.402 & 0.01 & 1.01 & 0.478 \\
\hline Residual L & 648 & 0 & & & 0 & & & 0 & & & 0 & & \\
\hline Residual DC & 648 & 0.003 & & & 0.001 & & & 0.004 & & & 0.003 & & \\
\hline Residual D & 324 & 0.004 & & & 0.001 & & & 0.006 & & & 0.002 & & \\
\hline Residual C & 324 & 0.008 & & & 0.002 & & & 0.002 & & & 0.003 & & \\
\hline Cochran's C-test & & \multicolumn{3}{|c|}{$0.309, \mathrm{p}<0.01$} & \multicolumn{3}{|c|}{$0.307, \mathrm{p}<0.01$} & \multicolumn{3}{|c|}{$0.406, \mathrm{p}<0.01$} & \multicolumn{3}{|c|}{$0.206, \mathrm{p}<0.01$} \\
\hline Transformation & & \multicolumn{3}{|c|}{$\operatorname{Ln}(x+1)$} & \multicolumn{3}{|c|}{$\operatorname{Ln}(x+1)$} & \multicolumn{3}{|c|}{$\operatorname{Ln}(x+1)$} & \multicolumn{3}{|c|}{$\operatorname{Ln}(\mathrm{x}+1)$} \\
\hline $\mathrm{S}-\mathrm{N}-\mathrm{K}$ test & & \multicolumn{3}{|c|}{$\mathrm{D} 2<\mathrm{D} 1<\mathrm{C} 2<\mathrm{C} 1$} & & & & \multicolumn{3}{|c|}{$\mathrm{D} 2<\mathrm{D} 1<\mathrm{C} 2<\mathrm{C} 1$} & \multicolumn{3}{|c|}{$\mathrm{D} 2<\mathrm{C} 1<\mathrm{D} 1<\mathrm{C} 2$} \\
\hline
\end{tabular}


Table 5. Major species, ranked in order of importance, contributing to the average dissimilarities between the disturbed and the control locations as determined by similarity percentages (SIMPER).

\begin{tabular}{|c|c|c|c|c|c|}
\hline \multirow[b]{2}{*}{ Species } & & $\mathrm{C}$ & \multicolumn{2}{|l|}{$\mathrm{D}$} & \\
\hline & & Av. $\%$ cover & Av. $\%$ cover & Av. Diss & $\%$. Contri \\
\hline Antithamnion sp & (Rhodophyta) & 44.83 & 2.57 & 5.32 & 9.53 \\
\hline Polysiphonia elongata (Hudson) Sprengel & (Rhodophyta) & 40.67 & 4.4 & 4.39 & 7.87 \\
\hline Ceramium tenuissimum (Roth) Aresch & (Rhodophyta) & 34.96 & 0.05 & 4.02 & 7.2 \\
\hline Ceramium codii (Richards) Mazoyer & (Rhodophyta) & 29.34 & 0 & 3.91 & 7 \\
\hline Dynamena cavolinii Neppi & (Hydrozoa) & 23.11 & 3.07 & 3.71 & 6.64 \\
\hline Spirorbis spirorbis Linnaeus & (Annelida) & 16.83 & 11.11 & 3.6 & 6.45 \\
\hline Scrupocellaria sp. & (Bryozoa) & 4.89 & 4.13 & 3.36 & 6.02 \\
\hline Bowerbankia imbricata Adams & (Bryozoa) & 3.09 & 4.2 & 3.29 & 5.9 \\
\hline Electra posidoniae Gautier & (Bryozoa) & 12.7 & 15.05 & 3.15 & 5.65 \\
\hline Lichenopora radiata Audouin & (Bryozoa) & 8.21 & 1.91 & 2.64 & 4.73 \\
\hline Micropora complanata Norman & (Bryozoa) & 12.94 & 4.25 & 2.13 & 3.82 \\
\hline Monotheca sp. & (Hydrozoa) & 3.07 & 2.92 & 1.96 & 3.51 \\
\hline Obelia geniculata Linnaeus & (Hydrozoa) & 3 & 2.97 & 1.63 & 2.92 \\
\hline Aetea truncata Landsborough & (Bryozoa) & 0.39 & 3.62 & 1.56 & 2.8 \\
\hline Halocordyle disticha Goldfuss & (Hydrozoa) & 0.77 & 0.1 & 1.44 & 2.58 \\
\hline Lyngbya sp. C. Agardh ex Gomont & (Cyanobacteria) & 0.71 & 0.39 & 1.29 & 2.31 \\
\hline Plumularia setacea Linnaeus & (Hydrozoa) & 0.75 & 0 & 1.23 & 2.2 \\
\hline Rivularia bullata (Poir) Berkeley & (Cyanobacteria) & 0.7 & 0.02 & 1.03 & 1.84 \\
\hline Gloeotrichia sp. & (Cyanobacteria) & 0 & 0.16 & 0.81 & 1.45 \\
\hline Chelidonia cordieri Audouin & (Bryozoa) & 0 & 0.01 & 0.76 & 1.36 \\
\hline Dasya. sp. & (Rhodophyta) & 4.83 & 1.52 & 0.72 & 1.29 \\
\hline Phormidium sp. & (Cyanobacteria) & 0.51 & 0 & 0.63 & 1.14 \\
\hline Griffithsia sp. & (Rhodophyta) & 0.4 & 0 & 0.54 & 0.97 \\
\hline Dasycladus vermicularis (Scopoli) Krasser & (Chlorophyta) & 0.17 & 0 & 0.53 & 0.95 \\
\hline Aglaophenia sp. & (Hydrozoa) & 0.06 & 0.02 & 0.5 & 0.9 \\
\hline Campanularia hincksi Alder & (Hydrozoa) & 0 & 0.02 & 0.18 & 0.33 \\
\hline Pleonosporium borreri (J.E.Smith) Nägeli & (Rhodophyta) & 0.01 & 0 & 0.18 & 0.32 \\
\hline Orthopyxis caliculata (Hincks) & (Hydrozoa) & 0.02 & 0 & 0.15 & 0.27 \\
\hline Cribrilina radiate $(\mathrm{Smitt})$ & (Bryozoa) & 0.01 & 0 & 0.14 & 0.25 \\
\hline
\end{tabular}


Table 6. Variance components expressed as percentage calculated for the epiphytic biomass and the epiphytic assemblages on leaves in the disturbed and the control locations $(\mathrm{D}=$ disturbed locations, $\mathrm{C}=$ control locations).

\begin{tabular}{|c|c|c|c|c|c|c|c|c|c|c|c|c|}
\hline \multirow[t]{2}{*}{$\begin{array}{c}\text { Source of } \\
\text { variation } \\
(\%)\end{array}$} & \multicolumn{2}{|c|}{ Biomass } & \multicolumn{2}{|c|}{ Whole assemblages } & \multicolumn{2}{|c|}{ Filamentous algae } & \multicolumn{2}{|c|}{ Bryozoans } & \multicolumn{2}{|c|}{ Hydrozoans } & \multicolumn{2}{|c|}{$\begin{array}{l}\text { Encrusting } \\
\text { Annelida }\end{array}$} \\
\hline & $\mathrm{C}$ & $\mathrm{D}$ & $\mathrm{C}$ & $\mathrm{D}$ & $\mathrm{C}$ & $\mathrm{D}$ & $\mathrm{C}$ & $\mathrm{D}$ & $\mathrm{C}$ & $\mathrm{D}$ & $\mathrm{C}$ & $\mathrm{D}$ \\
\hline Location & 8.75 & 8 & 0 & 6.46 & 18.57 & 0 & 0 & 0 & 17.6 & 11.36 & 31.28 & 24.55 \\
\hline Site & 10.22 & 0 & 18.59 & 0 & 0 & 9.8 & 39.6 & 5.72 & 0 & 12.04 & 13.94 & 0 \\
\hline Subsite & 0.00 & 3.56 & 0 & 4.67 & 3.6 & 19.85 & 0 & 22.3 & 15.65 & 0 & 9.14 & 0 \\
\hline Plot & 22.03 & 12.82 & 81.41 & 88.87 & 77.83 & 70.35 & 60.4 & 72 & 66.75 & 76.6 & 45.66 & 75.45 \\
\hline Quadrat & 0 & 26.83 & 0 & 0 & 0 & 0 & 0 & 0 & 0 & 0 & 0 & 0 \\
\hline
\end{tabular}


Table 7. Test of equality of mean variables studied for $P$. oceanica meadows. F:, df1, df2, Sig.:

\begin{tabular}{lccccc}
\hline & Wilks' Lambda & F & df1 & df2 & Sig. \\
\hline Biomass & 0.081 & 30.85 & 3 & 8 & 0 \\
Filamentous algae & 0.285 & 6.673 & 3 & 8 & 0.014 \\
Bryozoans & 0.967 & 0.092 & 3 & 8 & 0.962 \\
Hydrozoans & 0.131 & 17.61 & 3 & 8 & 0 \\
Encrusting Annelida & 0.363 & 4.66 & 3 & 8 & 0.036 \\
Leaf length & 0.373 & 4.476 & 3 & 8 & 0.04 \\
Shoot density & 0.015 & 175.4 & 3 & 8 & 0 \\
\hline
\end{tabular}


Table 8. Standardized canonical discriminant function coefficients of the studied variables for Posidonia oceanica.

\begin{tabular}{lccc}
\hline & \multicolumn{3}{c}{ Function } \\
\cline { 2 - 4 } & 1 & 2 & 3 \\
\hline Biomass & 1.143 & 1.52 & 0.07 \\
Hydrozoans & 2.523 & 1.287 & 0.866 \\
Encrusting Annelida & 0.608 & -0.79 & 0.984 \\
Shoot density & -2.992 & -0.898 & -0.287 \\
\hline
\end{tabular}




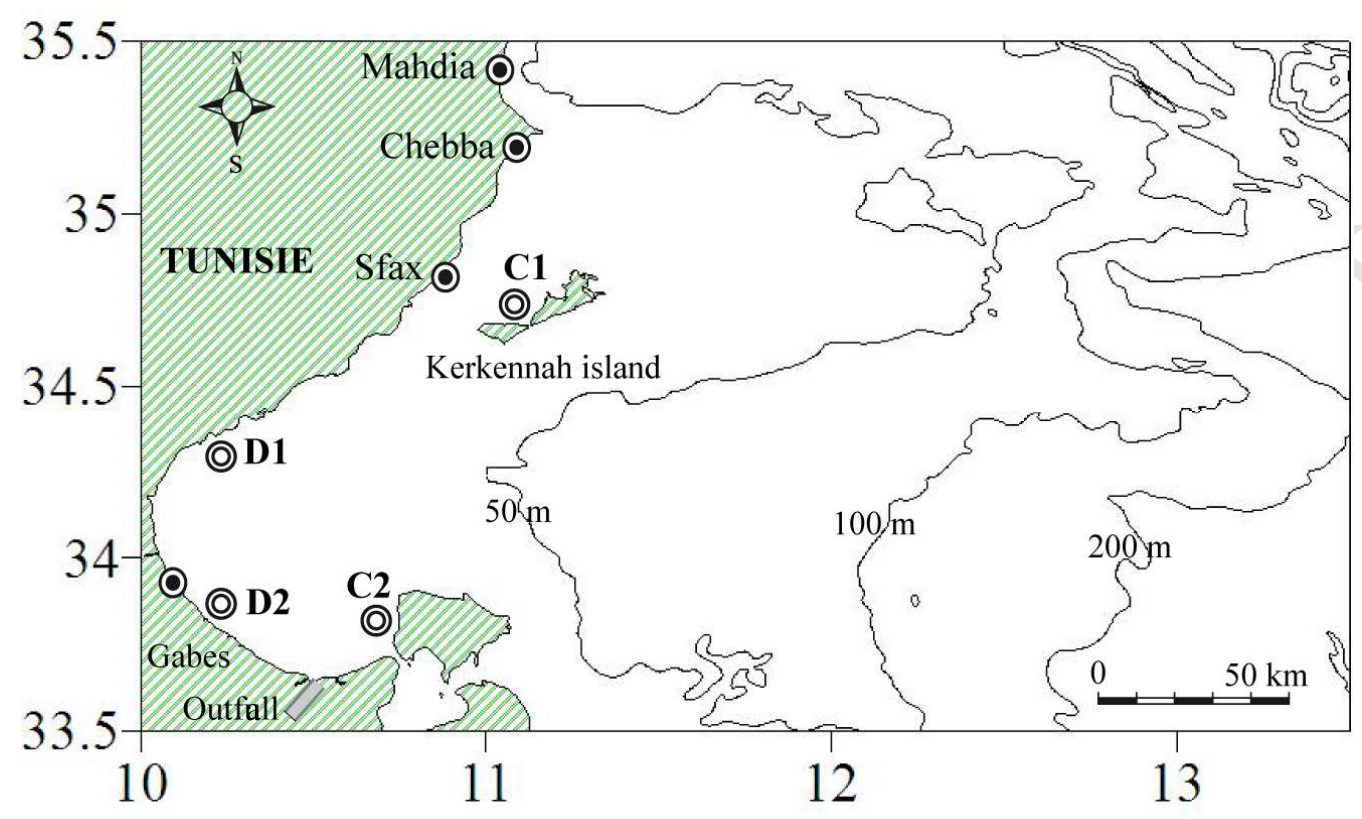

Figure 1. 


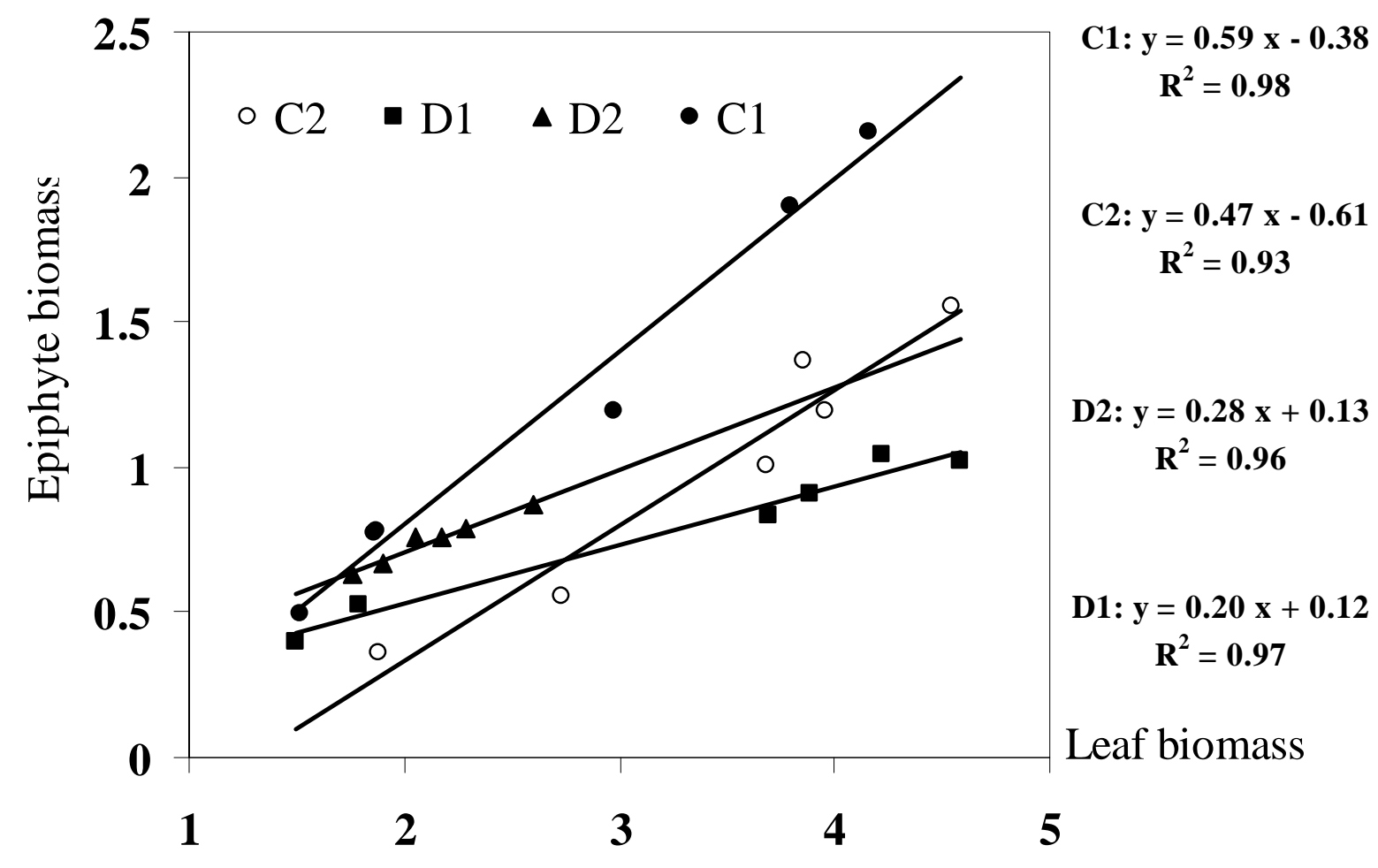

Figure 2. 


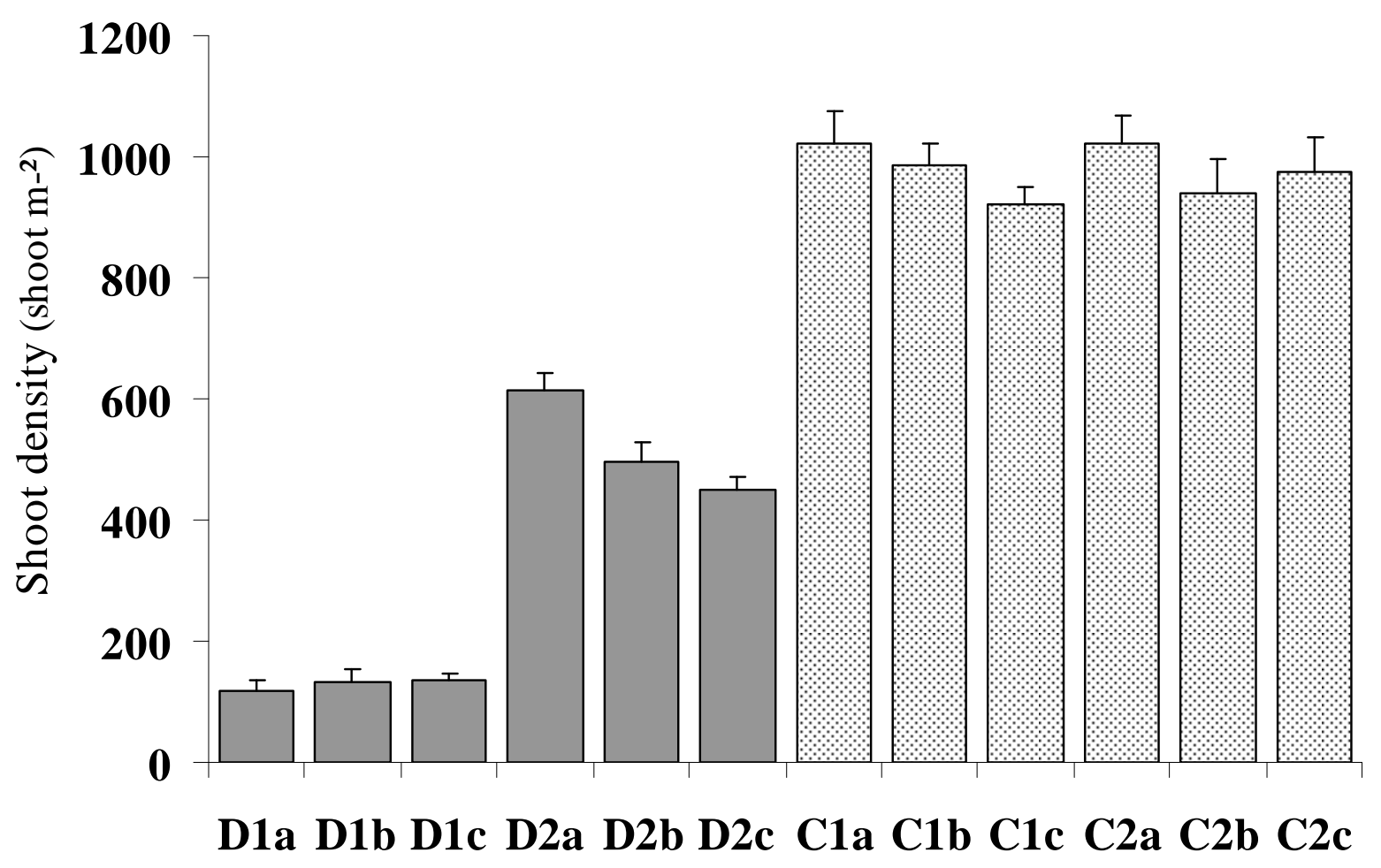

Figure 3. 


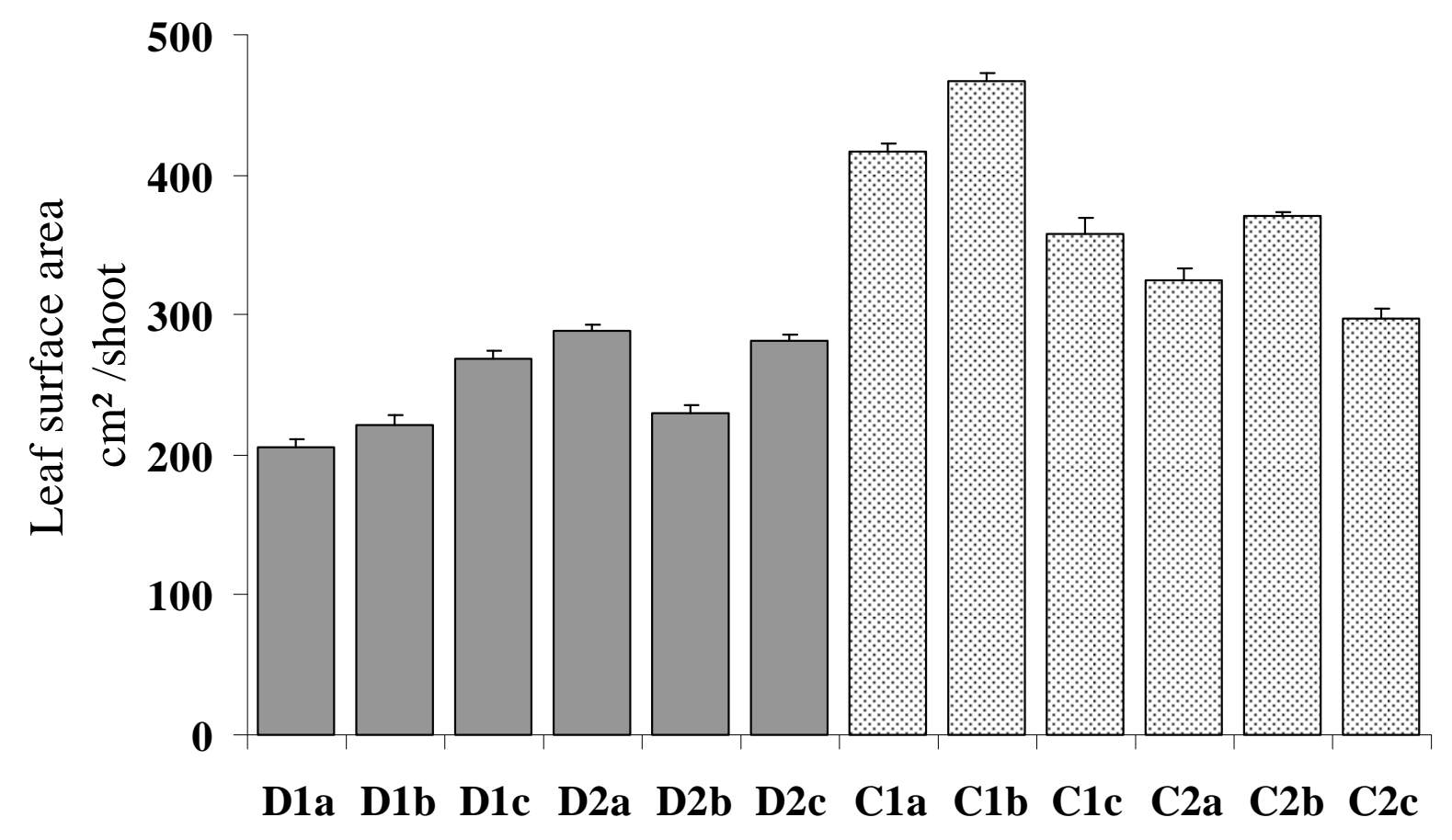

Figure 4. 


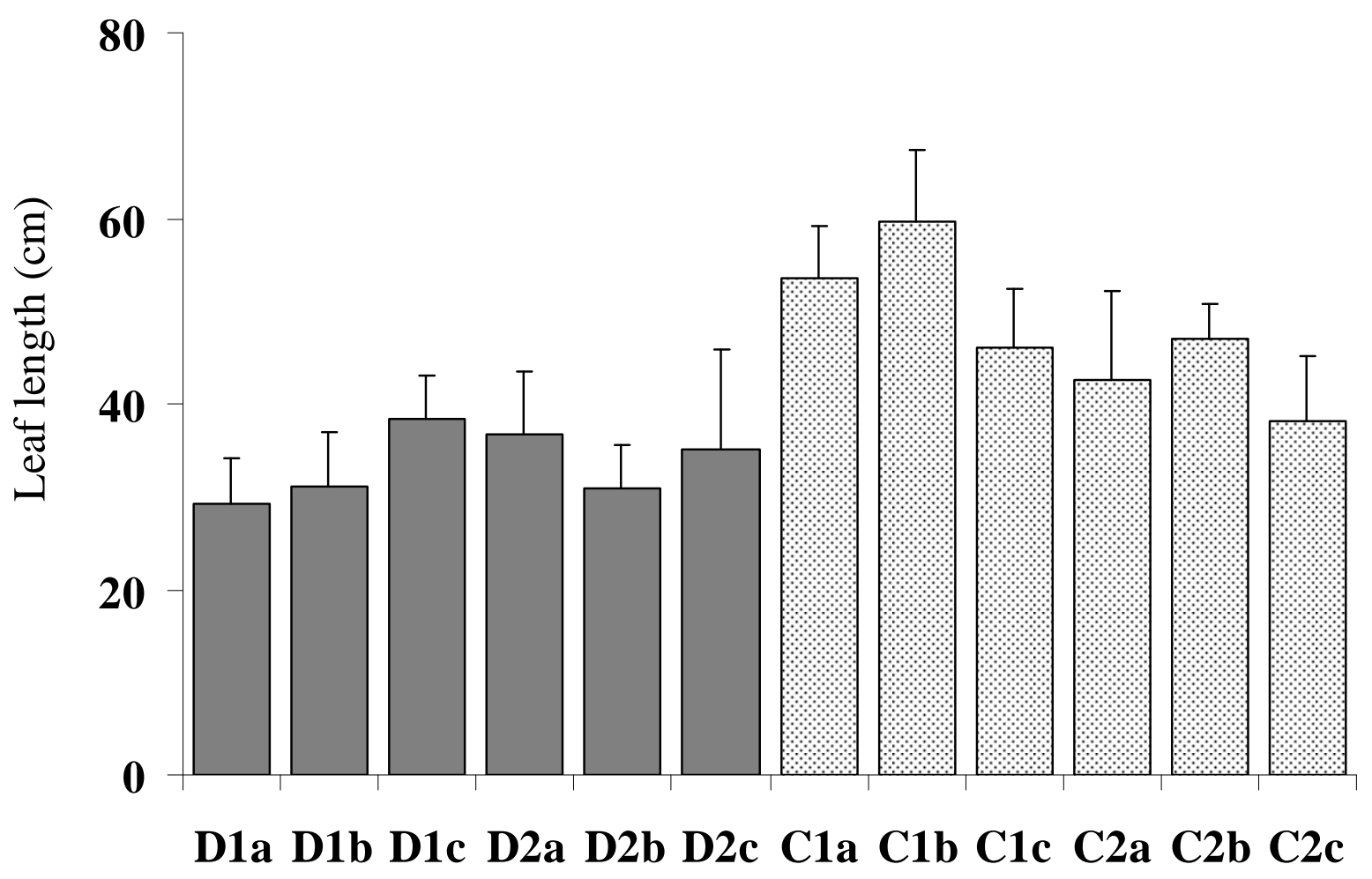

Figure 5. 


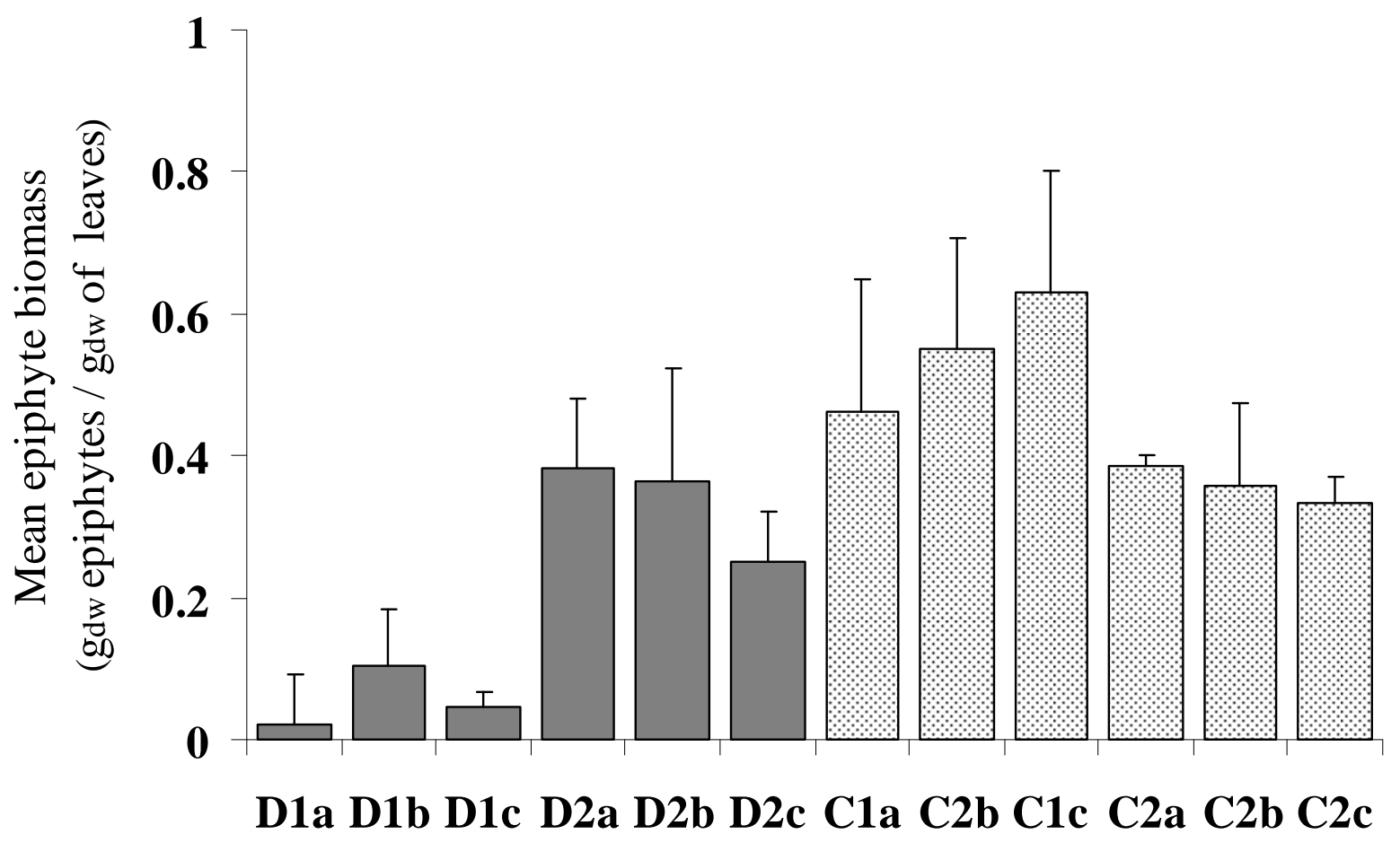

Figure 6. 

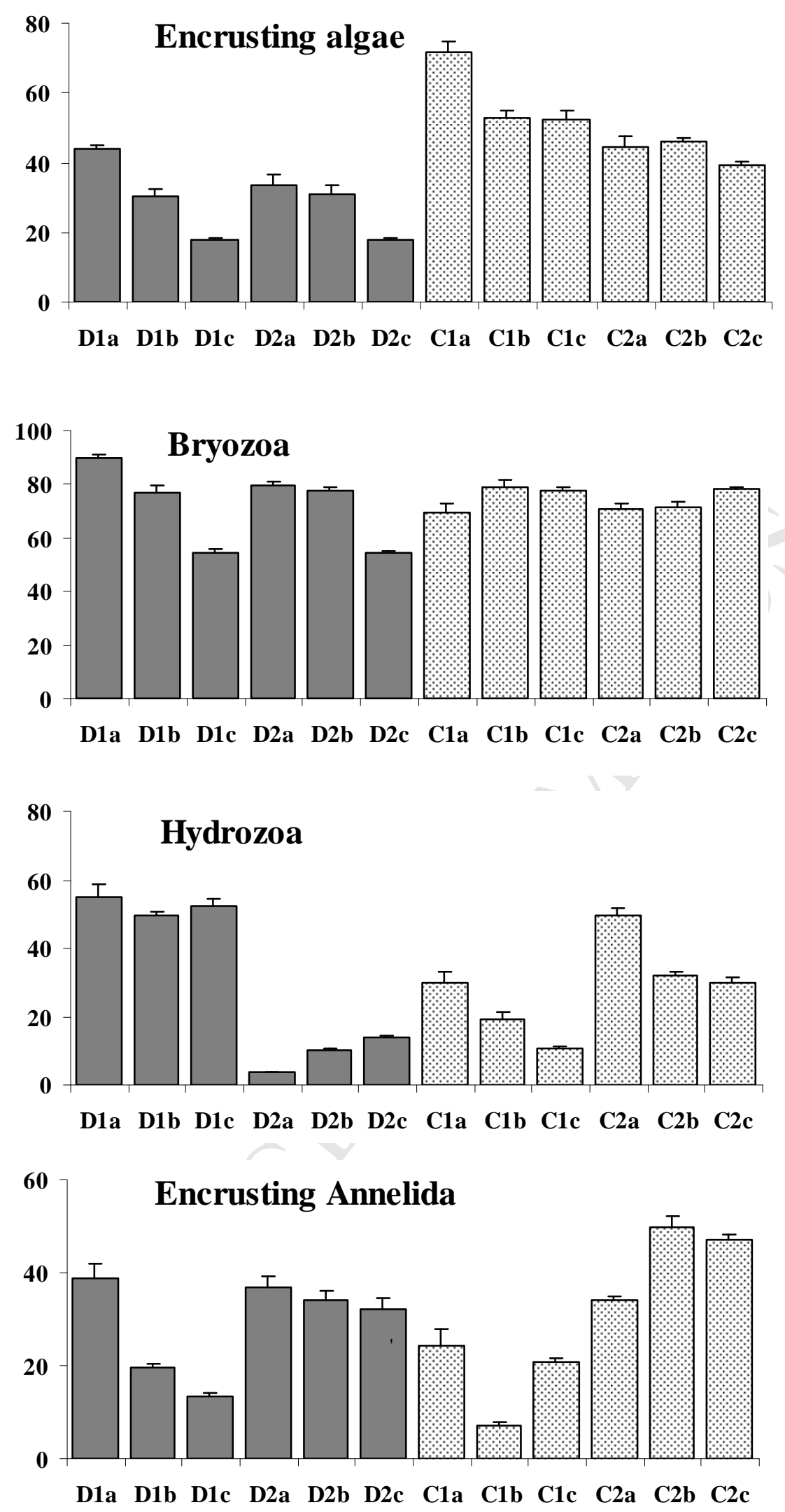

Figure 7. 

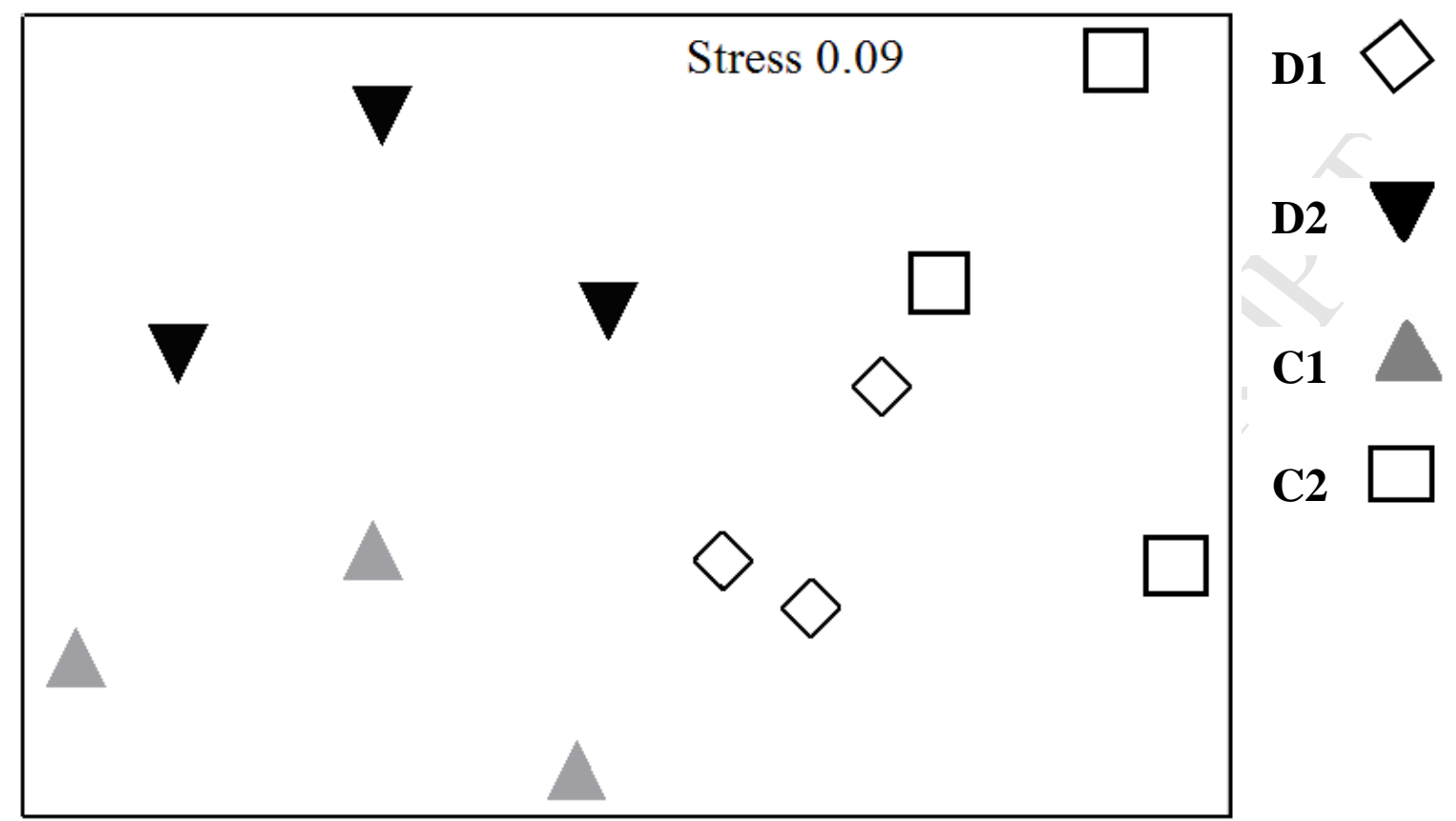

Figure 8. 


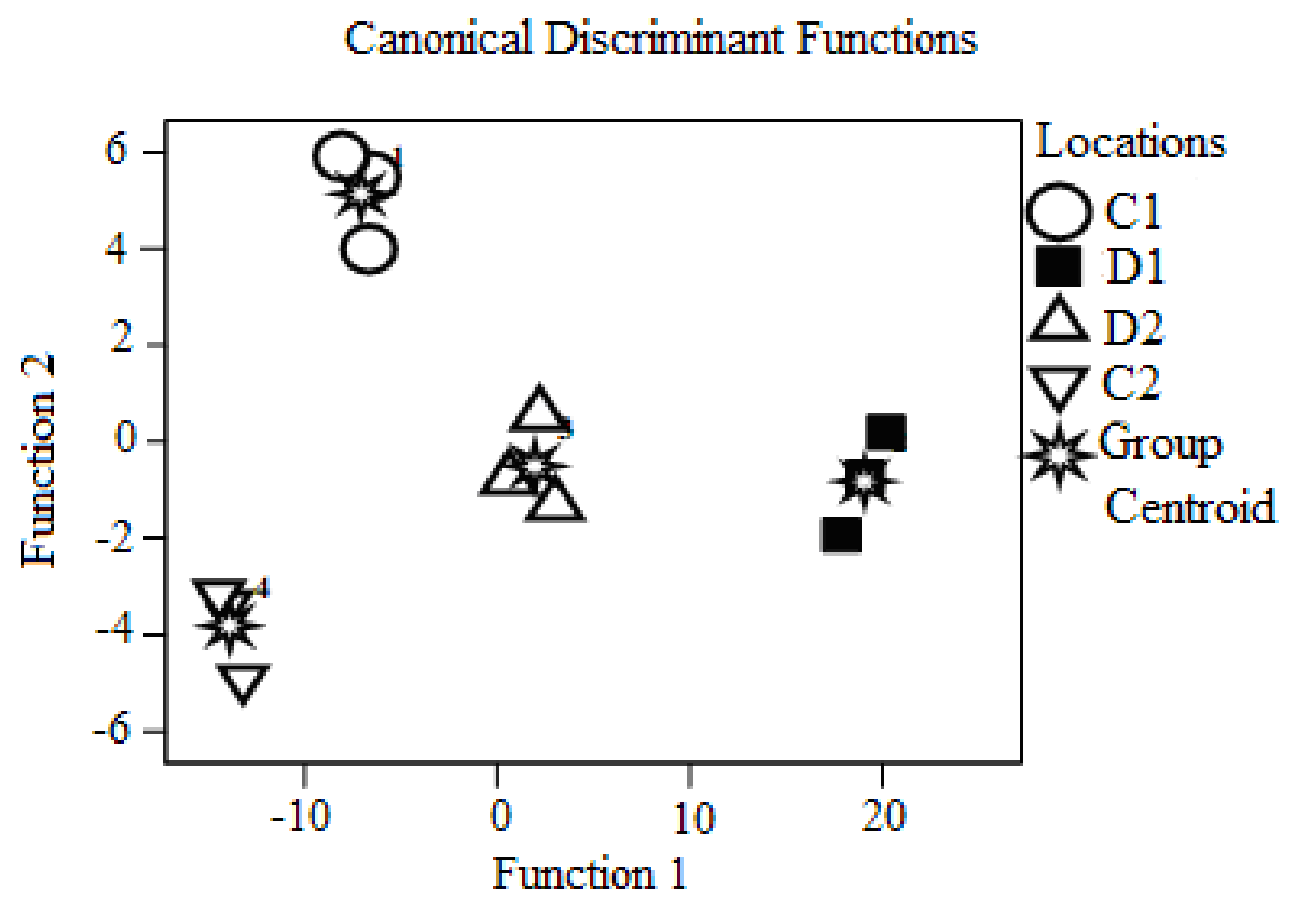

Figure 9. 
List of figures:

Figure 1. Geographical map focussing on sampling locations in the Gulf of Gabes.

Figure 2. Leaf biomass vs. epiphyte biomass $\left(\mathrm{g}_{\mathrm{dw}}\right.$ leaf $\left.^{-1}\right)$ for disturbed (D) and control (C) locations.

Figure 3. Average $\pm \mathrm{SD}$ values of the shoot density at the control $(\mathrm{C} 1, \mathrm{C} 2)$ and disturbed $\mathrm{D} 1$, D2) locations with the three nested sites $a, b$ and $c$.

Figure 4. Average $\pm \mathrm{SD}$ values of the leaf surface area at the control (C) and disturbed (D) locations with the three nested sites $\mathrm{a}, \mathrm{b}$ and $\mathrm{c}$.

Figure 5. Average \pm SD values of leaf length at the control (C) and disturbed (D) locations with the three nested sites $a, b$ and $c$.

Figure 6. Average $\pm \mathrm{SD}$ values of the mean biomass of leaf epiphytes of $P$. oceanica at the control (C) and disturbed (D) locations with the three nested sites a, b and c.

Figure 7. Mean percentage cover of the main epiphyte groups at the control and disturbed locations with the three nested sites a, b and c. (C1: Hassar; D1: Ghannouch; D2: Zarrat and C1: Ajim).

Figure 8. nMDS showing the dissimilarity among centroids of sites of epiphytic assemblages on leaves. Ghannouch: D1 $\diamond$, Zarrat: D2 , Hassar: C1, Ajim: C2.

Figure 9. Global projection on the first factorial design discriminating of variables and group centroids. 


\section{C}

D

Filamentous algae

\section{Chlorophyta}

Cladophora sp.

Dasycladus vermicularis (Scopoli) Krasser

\section{Heterokontophyta}

Dictyota dichotoma (Hudson) J.V Lamouroux

\section{Rhodophyta}

Antithamnion sp.

Ceramium codii (Richards) Mazoyer

Ceramium gracillimum (Kützing) Zanardini

Ceramium tenuissimum (Roth) Aresch

Dasya sp.

Falkenbergia rufolanosa (Harvey) F. Schmitz

Griffithsia opuntioides J. Agardh

Laurencia obtusa (Hudson) J.V. Lamouroux

Neomonospora sp.

Pleonosporium borreri (J.E.Smith) Nägeli

Polysiphonia elongate (Hudson) Sprengel

\section{1}

1

\section{Cyanobacteria}

\section{Calothrix sp.}

Gloeotrichia J. Agardh ex Bornet \& Flahault

Lyngbya sp.

Phormidium sp.

Rivularia bullata (Poir) Berkeley ex Bornet \& Flahault Rivularia mesenterica Thuret

\section{Hydrozoa}

Aglaophenia sp.

Campanularia hincksi Alder

Dynamena cavolinii Neppi

Gonothyraea gracilis M. Sars

Halocordyle disticha Goldfuss

Monotheca sp.

Obelia geniculata Linnaeus

Orthopyxis caliculata Hincks

Plumularia setacea Linnaeus

\section{Bryozoa}

Aetea truncata Landsborough

Alcyonidium sp.

Amathia lendigera Linnaeus

Beania hirtissima Heller

Bowerbankia imbricata Adams

Chelidonia cordieri Audouin

Cribrilina radiate Smitt

Electra posidoniae Gautier

Lichenopora radiata Audouin

Micropora complanata Norman

Scrupocellaria sp.

\section{Annelida}

1

1

1

0

1

1

1

1

1

1

1

0

0

1

1

1

1

1

1

1

Aphrodita sp. 
Brania clavata Claparede

Spirorbis spirorbis Linnaeus

Porifera

Halichondria sp.

Ircinia fasciculata Esper

Ircinia muscarum Schimd

\section{Tunicata}

Botryllus schlosseri Pallas

Clavelina lepadiformis (light-bulb sea squirt)

Total number of taxa
1

1

0

1

0

0

10

$1 \quad 0$

$1-1$

49

32

Appendix. Presence/absence of species and/or genus found growing on Posidonia oceanica leaves in the disturbed (D) and control locations (C) at Gabes gulf. 